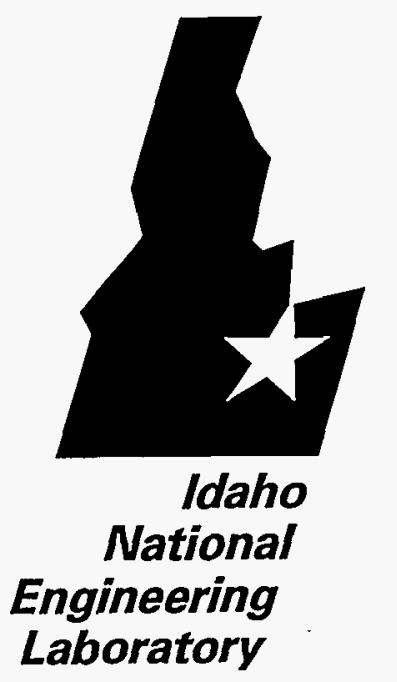

RECENES

OCT 201995

OSTI
INEL-9510101

February 1995

\title{
A Preliminary Survey of the National Wetlands Inventory as Mapped for the Idaho National Engineering Laboratory
}

N. L. Hampton

R. C. Rope

J. M. Glennon

K. S. Moor

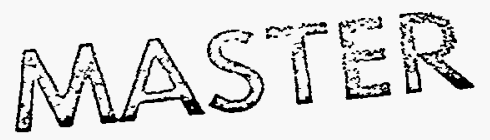

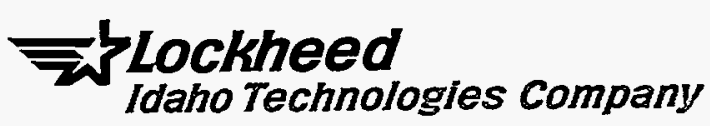

DISTRIBUTION OF THIS DOCUMENT IS UHLLWTED 


\section{DISCLAIMER}

Portions of this document may be illegible in electronic image products. Images are produced from the best available original document. 


\title{
A PRELIMINARY SURVEY OF THE NATIONAL WETLANDS INVENTORY AS MAPPED FOR THE IDAHO NATIONAL ENGINEERING LABORATORY
}

\author{
N. L. Hampton \\ R. C. Rope \\ J. M. Glennon \\ K. S. Moor \\ February 1995 \\ Environmental Assessment Technologies \\ Lockheed Idaho Technologies, Inc. \\ Idaho Falls, ID 83415
}

\author{
Prepared for \\ U.S. Department of Energy \\ Idaho Operations Office \\ Under DOE Contract No. DE-AC07-94ID013223
}




\section{ACKNOWLEDGEMENTS}

The authors thank Randy Lee for his support on data analysis and GIS mapping for this report and Dena Tomchak and Marilynne Manguba for administrative and word processing support.

\section{DISCLAIMER}

This report was prepared as an account of work sponsored by an agency of the United States Government. Neither the United States Government nor any agency thereof, nor any of their employees, makes any warranty, express or implied, or assumes any legal liability or responsibility for the accuracy, completeness, or usefulness of any information, apparatus, product, or process disclosed, or represents that its use would not infringe privately owned rights. Reference herein to any specific commercial product, process, or service by trade name, trademark, manufacturer, or otherwise does not necessarily constitute or imply its endorsement, recommendation, or favoring by the United States Government or any agency thereof. The views and opinions of authors expressed herein do not necessarily state or reflect those of the United States Government or any agency thereof. 


\begin{abstract}
Approximately 135 areas within the boundaries of the Idaho National Engineering Laboratory (INEL) have been mapped as wetland habitat as part of the United States Fish and Wildlife Service (FWS) National Wetlands Inventory (NWI). A preliminary survey of these wetlands was conducted to examine their general characteristics and status, to provide an estimation of relative ecological importance, to identify additional information needed to complete ecological characterization of important INEL wetlands, and to identify high priority wetland areas on the INEL. The purpose of the survey was to provide information to support the preparation of the Environmental Restoration and Waste Management (ER\&WM) Environmental Impact Statement (EIS). Information characterizing general vegetation, hydrology, wildlife use, and archaeology was collected at 105 sample sites on the INEL. Sites representing NWI palustrine, lacustrine, and riverine wetlands (including manmade), and areas unmapped or unclassified by the NWI were included in the sample. The field information was used to develop a preliminary ranking of relative ecological importance for each wetland visited during this survey. Survey limitations are identified.
\end{abstract}




\section{CONTENTS}

ABSTRACT $\ldots \ldots \ldots \ldots \ldots \ldots \ldots \ldots \ldots \ldots \ldots \ldots \ldots \ldots \ldots \ldots \ldots$

ACRONYMS AND ABBREVIATIONS $\ldots \ldots \ldots \ldots \ldots \ldots \ldots \ldots \ldots \ldots$

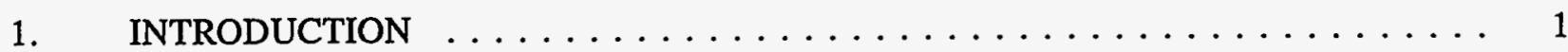

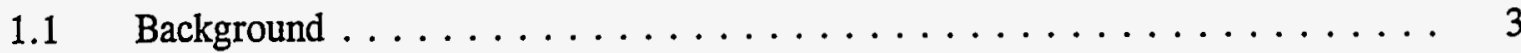

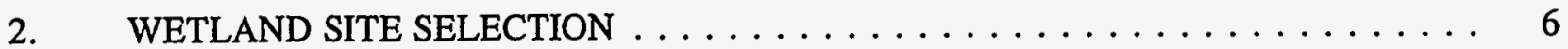

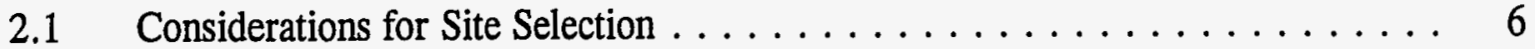

3. FIELD SURVEY METHODS $\ldots \ldots \ldots \ldots \ldots \ldots \ldots \ldots \ldots \ldots$

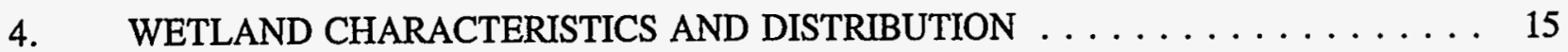

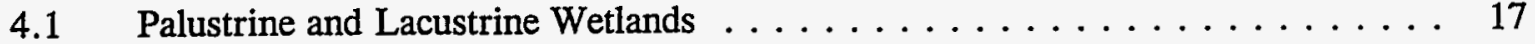

4.1 .1 PUSJ Classified Wetlands . . . . . . . . . . . . . . . . . . 17

4.1.2 L2USJ, PEM1A, PEM1C, PEM1J, and PEMJ Classified Wetlands . . . 19

4.2 Riverine Wetlands . . . . . . . . . . . . . . . . . . . 23

4.3 Manmade Wetlands . . . . . . . . . . . . . . . . . 26

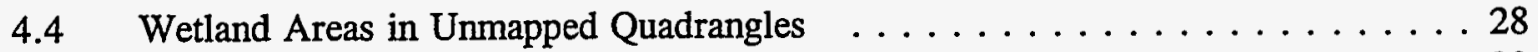

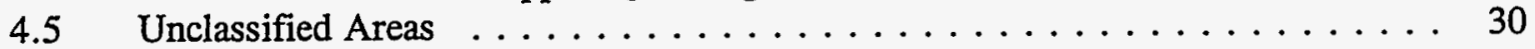

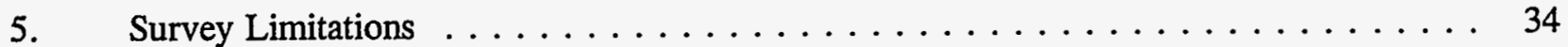

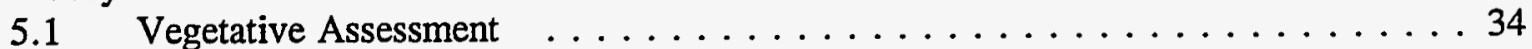

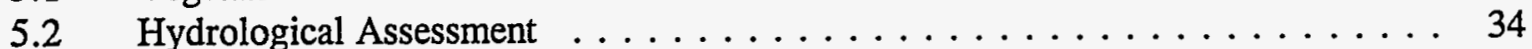

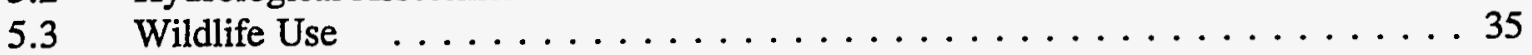

5.4 Archaeological and Paleoecological Assessment $\ldots \ldots \ldots \ldots \ldots \ldots \ldots \ldots$

5.5 Soil Assessment . . . . . . . . . . . . . . . . . . . 36

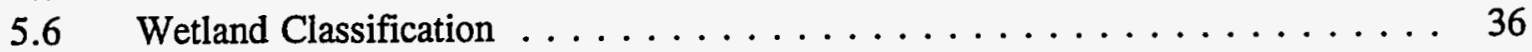

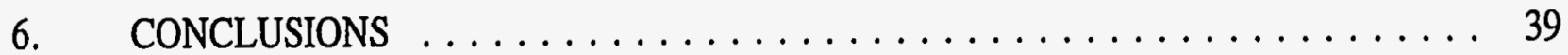

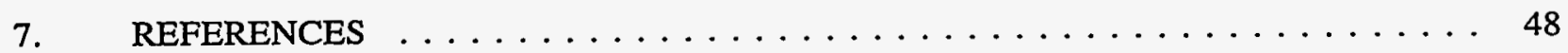

APPENDIX A - WETLAND GIS FIELD DOCUMENTATION FORMS

APPENDIX B - INEL WETLANDS SURVEY DATA

APPENDIX C - INEL WETLAND SURVEY - PLANT SPECIES LIST

APPENDIX D - GIS MAP OF INEL NWI WETLANDS 


\section{FIGURES}

Figure 1. USGS 7.5' Quadrangle Coverage for the INEL. . . . . . . . . . . 7

Figure 2. Examples of Site Definition for Polygons and Linear Features. . . . . . . . . . . 9

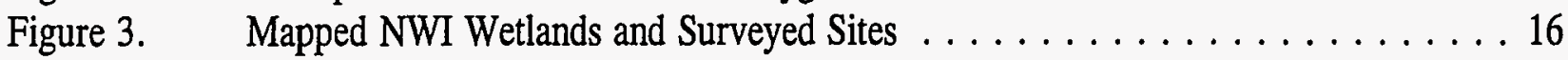

Figure 4. Surveyed PUSJ Wetlands of the INEL . . . . . . . . . . . . . 18

Figure 5. Surveyed Palustrine and Lacustrine Wetland Sites of the INEL. . . . . . . . 20

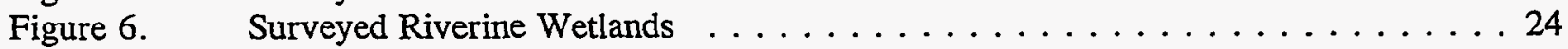

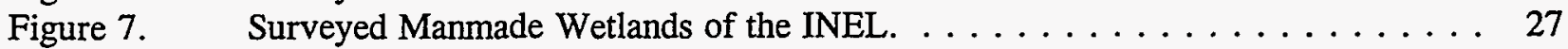

Figure 8. Surveyed Unmapped and Unclassified Areas on the INEL. . . . . . . . . . 32

Figure 9. NWI Mapped Areas of the Big Lost River and Birch Creek Drainages on the INEL. 42

\section{TABLES}

Table 1. Definition of INEL Wetlands survey site Classifications. . . . . . . . . 8

Table 2. Summary of Vegetation Observed at Sampled PUSJ Wetland Sites. . . . . . . . 19

Table 3. Summary of Vegetation Observed at Sampled Palustrine and

Lacustrine Wetland Sites. . . . . . . . . . . . . . . . . . . 22

Table 4. Summary of Vegetation Observed at Sampled Riverine Wetland Sites. . . . . . 25

Table 5. Summary of Vegetation Observed at Sampled Manmade Wetland Sites. . . . . . 29

Table 6. Summary of Vegetation Observed at Sampled Unmapped Wetland Sites. . . . . . 31

Table 7. Summary of Vegetation Observed at Sampled Unclassified Wetland Sites. . . . 33 


\section{ACRONYMS AND ABBREVIATIONS}

$\begin{array}{ll}\text { COE } & \text { U.S. Army Corps of Engineers } \\ \text { DOE } & \text { U.S. Department of Energy } \\ \text { EIS } & \text { Environmental Impact Statement } \\ \text { ER\&WM } & \text { Environmental Restoration and Waste Management } \\ \text { FWS } & \text { U.S. Fish and Wildlife Service } \\ \text { GIS } & \text { geographic information system } \\ \text { GPS } & \text { global positioning system } \\ \text { INEL } & \text { Idaho National Engineering Laboratory } \\ \text { IRC } & \text { INEL Research Center } \\ \text { NEPA } & \text { National Environmental Policy Act } \\ \text { NWI } & \text { National Wetlands Inventory } \\ \text { PTI } & \text { Protection Technology Inc. } \\ \text { NRCS } & \text { Natural Resources Conservation Service } \\ \text { USGS } & \text { U.S. Geological Survey }\end{array}$




\section{A PRELIMINARY SURVEY OF NWI WETLANDS ON THE IDAHO NATIONAL ENGINEERING LABORATORY}

\section{INTRODUCTION}

A preliminary survey of wetland habitats located on the Idaho National Engineering Laboratory (INEL) was conducted in the Fall of 1992 to: (a) examine the general characteristics of INEL wetlands, (b) assess the current status of those wetlands, (c) provide a preliminary evaluation of the relative ecological importance of wetlands on the INEL, (d) identify information needed for further ecological characterization of important INEL wetlands, and (e) identify high priority wetland areas on the INEL. The purpose of the survey was to provide preliminary information to support the preparation of the Environmental Restoration and Waste Management (ER\&WM) Environmental Impact Statement (EIS) and to provide initial screening information to identify favorable and unfavorable locations for new facilities (i.e., roads, buildings, etc.). The survey was not intended to delineate wetland areas or serve as an accuracy assessment of the wetlands that have been mapped by the National Wetlands Inventory.

Approximately 135 areas within the boundaries of the INEL have been identified and mapped as part of the United States Fish and Wildlife Service (FWS) National Wetlands Inventory (NWI) The NWI is a program instituted to characterize and map the nation's wetland resources. NWI wetlands are delineated using the FWS official wetlands classification system (Cowardin, et al., 1979). To develop the NWI wetland maps, hydrological, vegetative, and soil characteristics are analyzed using high altitude aerial photography, Natural Resources Conservation Service (NRCS) soil surveys, and United States Geological Survey (USGS) topographical maps (FWS, 1990). Draft maps are distributed to interested parties in federal and state agencies and the public for further verification. The finalized maps provide information and guidelines for wetland management. Lands assigned wetland status under the NWI may be subject to regulation and management by a number of federal, state, and local governmental agencies, however, NWI maps are not intended to define agency jurisdiction (Wilen, 1988).

1 Total was determined by counting the number of polygons or linear segments mapped by the NWI. 
A brief overview of NWI mapping conventions and FWS classification definitions are presented in Section 2. The considerations used to select the INEL wetlands sampled for this survey are also discussed in Section 2. Section 3 describes the methodology for field data collection. A completed example of the Wetland/GIS Field Documentation Form is included in Appendix A. Wetland characteristics based on survey data are summarized in Section 4.

For ease of discussion, INEL wetlands have been grouped into five categories: palustrine and lacustrine (Section 4.1), riverine (Section 4.2), manmade (Section 4.3), unmapped (Section 4.4) and unclassified (Section 4.5). The general characteristics discussed for each category include size, vegetative and hydrological characteristics, wildlife presence and archaeological evidence. The survey data for individual sites are numbered and summarized in Appendix B, Table B-1. Site numbers associated with Table B-1 may be used to identify individual wetlands on the map in Appendix D. Section 5 contains a discussion of survey limitations in relation to FWS classification and characterization of particular INEL wetlands. Survey findings are summarized in Section 6.

The information from this survey can be used to: (a) locate NWI mapped wetlands and other surveyed areas using the GIS generated map included in Appendix D, (b) determine basic characteristics associated with a wetland class (Section 5), or (c) review survey results, characteristics, and relative importance for specific wetlands in either summarized form (Table B-1) or from field data collection forms and photographs (available from Environmental Assessment Technologies).

INEL activities involving facility siting, mitigation, remediation, and environmental restoration should use this map and survey information to determine the following for the areas where these activities are taking place:

1. If there are NWI classified wetlands in the area

2. If there is survey information for these areas

3. If the physical/biological characteristics where the activities are taking place are similar to the wetlands that were surveyed

4. If the wetlands surveyed have potential ecological significance 
5. The additional information necessary to fully characterize the surveyed sites as wetlands, their potential ecological significance, and possible mitigation needs if degradation of the area occurs.

\subsection{Background}

The NWI maps used for this survey were finalized prior to adoption of the Federal Manual for Identifying and Delineating Jurisdictional Wetlands (Federal Interagency Comittee for Wetlands Delineation, 1989) (referred to as the Federal Manual). This manual was developed in a cooperative effort between the Environmental Protection Agency (EPA), Army Corps of Engineers (COE), NRCS and FWS to provide "mandatory technical criteria, field indicators, and recommended methods for identifying and delineating jurisdictional wetlands".

Under Department of Energy (DOE) General Provisions, 10 CFR 1022.4(v), 1992, (DOE, 1992) wetlands are defined as:

"..areas that are inundated by surface or groundwater with a frequency sufficient to support and under normal circumstances does or would support a prevalence of vegetative or aquatic life that requires saturated or seasonally saturated soil conditions for growth and reproduction. Wetlands generally include swamps, marshes and bogs, and similar areas such as sloughs, potholes, wet meadows, river overflow, mudflats, and natural ponds."

The definition is similar to EPA, COE, NRCS and FWS wetlands definitions and although wording may vary among agencies, all address three primary criteria [as summarized from the federal manual (Federal Interagency Committee for Wetlands Delineation, 1989)]. These criteria include:

1. Hydrophytic Vegetation - Hydrophytic vegetation is defined as "macrophytic plant life growing in water, soil or on a substrate that is at least periodically deficient in oxygen as a result of excessive water content." Wetland plant species have been assigned indicator status based on the frequency with which the species is found in wetlands (Reed, 1988). Obligate Wetland plants occur almost always in natural wetlands (estimated probability $>99 \%$ ). Obligate Upland plants include those species that occur in non-wetlands (estimated probability 
$>99 \%$ ). Facultative Wetland plants usually occur in wetlands (estimated probability 67 to $99 \%$ ), but are occasionally found in non-wetlands. Plants equally likely to occur in nonwetlands as in wetlands (estimated probability 34 to 66\%) are designated Facultative. Facultative Upland plants generally occur in non-wetlands (estimated probability 67\%-99\%), however are occasionally found in wetlands ( 1 to $33 \%$ ).

2. Hydric Soils - Hydric soils are saturated, flooded or ponded long enough during the growing season to develop anaerobic conditions in the upper part. These soils generally support hydrophytic vegetation.

3. Wetland Hydrology - Wetland hydrology is indicated by permanent or periodic inundation or soil saturation to the surface, at least seasonally.

Two primary differences exist between the FWS wetlands definition and those of the EPA and COE. The first is the "recognition by FWS of both vegetated and non-vegetated areas (e.g., mudflats, sand flats, rocky shores, gravel beaches and sand bars)" (Federal Interagency Committee for Wetland Delineation, 1989). The EPA/COE definition includes the statement "wetlands generally include swamps, marshes, bogs, and similar areas" (Federal Interagency Committee for Wetland Delineation, 1989). The DOE definition is phrased the same as the EPA/COE definition except that the concluding line states that "wetlands generally include swamps, marshes, bogs, sloughs, potholes, wet meadows, river overflow, mudflats, and natural ponds" [10 CFR 1022.4(v), 1992]. The FWS recognizes the existence of wetlands that lack vegetation and or soil, especially in arid and semiarid regions (Tiner, 1989). Inclusion of mudflats in the DOE definition conflicts with the three criteria requirement because these areas are considered non-vegetated wetlands by the FWS.

The second difference is the way in which the technical criteria (hydrophytic vegetation, hydric soils and wetland hydrology) are applied for wetland delineation. All three criteria must be met under the EPA/COE definition, whereas the FWS delineation is based primarily on hydrological indicators and habitat features. A more detailed interpretation of the DOE definition is required before verification of INEL wetland characteristics based on the technical criteria in the federal manual can be considered conclusive. 
The use of NWI, USGS and NRCS maps, as well as other state and agency wetland program information for wetland characterization is prescribed under DOE General Provisions

[10 CFR 1022.11(c)] (DOE, 1992). However, technical criteria to be applied in assessing vegetation, soils and hydrology are not specified. Consequently, technical criteria drawn from the 1989 federal manual were used to develop data collection requirements and field methodology for this survey. NWI wetlands maps, USGS 7.5' topographic maps and aerial photographs (1991, 1:40,000) were the primary sources of information for the survey.

It is unclear whether the DOE definition requires application of mandatory technical criteria conforming to the EPA/COE definitions. The NWI sites for which wetland vegetation and/or wetland hydrologic criteria were confirmed satisfy the FWS wetland criteria requirements. However, no verification with regard to the EPA/COE three criteria requirement can be made for these sites without confirmation of hydric soils. Collection of soils data was beyond the scope of this preliminary survey.

Since the completion of the INEL survey (November, 1992), proposed revisions to the 1989 manual (EPA, 1991) have been challenged. Environmental organizations, scientific groups, and some state and local officals have been concerned that proposed changes may adversely affect millions of acres of wetlands. Pending resolution of questions regarding wetland delineation criteria, the EPA and COE have adopted the Corps of Engineers Wetlands Delineation Manual (1987). It is unclear whether the FWS will also use the 1987 manual. 


\section{WETLAND SITE SELECTION}

The geographic coverage of the INEL includes thirty, 7.5' USGS topographic quadrangles. Finalized or draft NWI maps have been generated for twenty-five of these quadrangles (Figure 1). Designated wetlands from the completed NWI inventory maps were digitized and entered into a geographic information system (GIS) at the INEL. A map of INEL wetlands was created and combined with other coverages already available in the GIS database.

FWS NWI classification and mapping procedures are well documented (Cowardin, 1979; FWS, 1990). Sixteen separate classifications are represented by approximately 135 wetland areas and stream segments within INEL boundaries. These NWI classifications are denoted by a descriptive acronym assigned by the FWS and are defined on Table 1 . Two additional classes were created for this survey to include investigation of: (a) potential wetlands that exist in the five quadrangles not yet mapped by the FWS NWI (UNMAP) and (b) areas within the mapped quadrangles that have characteristics similar to mapped wetlands, but were not classified as wetlands (UNCLASS).

INEL wetland areas classified as palustrine and lacustrine by the NWI are generally delineated as polygons on USGS 7.5' topographical maps. For this survey, each polygon representing homogeneous characteristics was defined as a single site. Riverine features mapped by the NWI are represented by line segments. Several short segments (approximately $100 \mathrm{~m}$ ) along the length of these features were visited and described. Each of these shorter segments was defined as a single site. Examples of site definition for polygons and linear features are shown on Figure 2. These conventions were also applied to unmapped and unclassified wetlands included in the survey.

\subsection{Considerations for Site Selection}

Approximately 100 sites representing wetlands for all classifications on the INEL were selected for the survey (Table 1). The following considerations were used to select a sample that would provide a good representation of the wetlands distributed across the INEL and meet the objectives of this survey: 


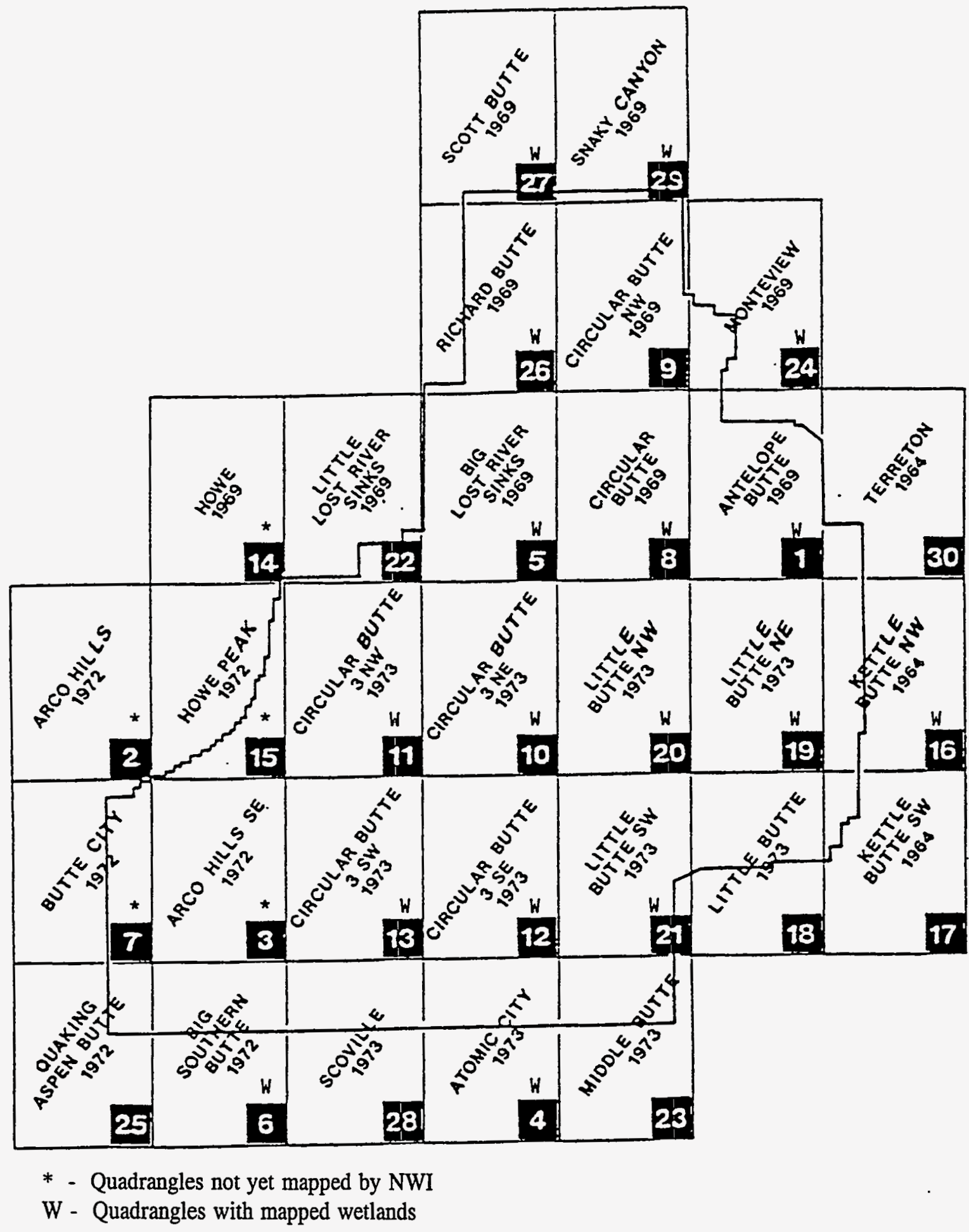

Figure 1. USGS 7.5' quadrangle coverage for the INEL. 
Table 1. Definition of INEL NWI mapped wetlands survey site classifications.

\begin{tabular}{|c|c|c|c|}
\hline $\begin{array}{l}\text { WETLAND } \\
\text { ACRONYM } \\
\text { (Type) }\end{array}$ & WETLAND CLASSIFICATION WITH MODIFIERS & $\begin{array}{l}\text { TOTAL NWI } \\
\text { MAPPED } \\
\text { WETLANDS } \\
\text { ON THE } \\
\text { INEL }\end{array}$ & $\begin{array}{c}\text { NUMBER } \\
\text { OF } \\
\text { WETLAND } \\
\text { SITES } \\
\text { SURVEYED }\end{array}$ \\
\hline \multicolumn{4}{|c|}{ NWI Classifications } \\
\hline PAB4Hx & $\begin{array}{l}\mathrm{P}=\text { Palustrine }, \mathrm{AB}=\text { Aquatic Bed, } 4=\text { Floating Vascular, } \mathrm{H}=\text { Permanently } \\
\text { Flooded, } \mathrm{x}=\text { Excavated }\end{array}$ & 1 & 1 \\
\hline PEM1A & $\begin{array}{l}\mathrm{P}=\text { Palustrine, } \mathrm{EM}=\text { Emergent (Vegetation), } 1=\text { Persistent, } \\
\mathrm{A}=\text { Temporarily Flooded }\end{array}$ & 5 & 1 \\
\hline PEMIC & $\begin{array}{l}\mathrm{P}=\text { Palustrine, } \mathrm{EM}=\text { Emergent (Vegetation), } \mathrm{I}=\text { Persistent, } \mathrm{C}=\text { Seasonally } \\
\text { Flooded }\end{array}$ & 2 & 2 \\
\hline PEM1J & $\begin{array}{l}\mathrm{P}=\text { Palustrine, } \mathrm{EM}=\text { Emergent (Vegetation), } 1=\text { Persistent, } \\
\mathrm{J}=\text { Intermittently Flooded }\end{array}$ & 2 & 2 \\
\hline PEMJ & $\mathrm{P}=$ Palustrine, $\mathrm{EM}=$ Emergent (Vegetation) $\mathrm{J}=$ Intermittently Flooded & 2 & 2 \\
\hline POWHx & $\begin{array}{l}P=\text { Palustrine }, O W=\text { Open Water, } H=\text { Permanently Flooded, } \\
\mathrm{x}=\text { Excavated }\end{array}$ & 14 & 11 \\
\hline PUSC & $\mathrm{P}=$ Palustrine, $\mathrm{US}=$ Unconsolidated Shore, $\mathrm{C}=$ Seasonally Flooded & 1 & 1 \\
\hline PUSCrx & $\begin{array}{l}\mathrm{P}=\text { Palustrine }, \mathrm{US}=\text { Unconsolidated Shore }, \mathrm{C}=\text { Seasonally Flooded, } \\
\mathrm{r}=\text { Artificial Substrate, } \\
\mathrm{x}=\text { Excavated }\end{array}$ & 2 & 2 \\
\hline PUSCX & $\begin{array}{l}\mathrm{P}=\text { Palustrine, } U S=\text { Unconsolidated Shore, } C=\text { Seasonally Flooded, } \\
\mathrm{x}=\text { Excavated }\end{array}$ & 1 & 1 \\
\hline PUSJ & $\mathrm{P}=$ Palustrine, $\mathrm{US}=$ Unconsolidated Shore, $\mathrm{J}=$ Intermittently Flooded & 88 & 45 \\
\hline L2USJ & $\begin{array}{l}\mathrm{L}=\text { Lacustrine, } 2=\text { Littoral, US=Unconsolidated Shore, } \mathrm{J}=\text { =Intermittently } \\
\text { Flooded }\end{array}$ & 5 & 4 \\
\hline R2OWHx & $\begin{array}{l}\mathrm{R}=\text { Riverine }, 2=\text { Lower Perennial, } \mathrm{OW}=\text { Open Water, } \mathrm{H}=\text { Permanently } \\
\text { Flooded, } \mathrm{x}=\text { Excavated }\end{array}$ & 1 & 1 \\
\hline R4SBA & $\mathrm{R}=$ Riverine, $4=$ Intermittent, $\mathrm{SB}=$ Streambed, $\mathrm{A}=$ Temporarily Flooded & 2 & 1 \\
\hline R4SBC & $\mathrm{R}=$ Riverine, $4=$ Intermittent, $\mathrm{SB}=$ Streambed, $\mathrm{C}=$ Seasonally Flooded & 2 & 1 \\
\hline R4SBKCX & $\begin{array}{l}\mathrm{R}=\text { Riverine }, 4=\text { Intermittent, } \mathrm{SB}=\text { Streambed, } \mathrm{K}=\text { Artificially Flooded, } \\
\mathrm{C}=\text { Seasonally Flooded, } \mathrm{x}=\text { Excavated }\end{array}$ & 2 & 0 \\
\hline R4SBJ & $\mathrm{R}=$ Riverine, $4=$ Intermittent, $\mathrm{SB}=$ Streambed, $\mathrm{J}=$ Intermittently Flooded & 3 & 1 \\
\hline R4SBJX & $\begin{array}{l}R=\text { Riverine }, 4=\text { Intermittent, } S B=\text { Streambed, } J=\text { Intermittently Flooded, } \\
x=\text { Excavated }\end{array}$ & 2 & 2 \\
\hline & TOTAL NWI CLASSIFICATIONS & 135 & 78 \\
\hline \multicolumn{4}{|c|}{ Special Survey Classifications } \\
\hline UNCLASS & UNCLASS = Area not classified as a wetland by NWI & Unknown & 29 \\
\hline \multirow[t]{2}{*}{ UNMAP } & UNMAP $=$ NWI maps not complete & Unknown & 14 \\
\hline & TOTALS & Unknown & 121 \\
\hline
\end{tabular}


1) Each polygon represents one site:

EXAMPLE: 3 sites classified as PUSI
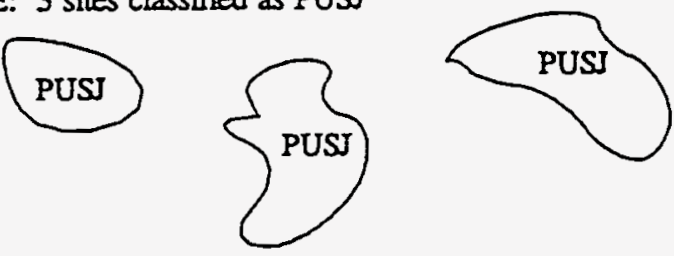

2) Each polygon represents a separate site

EXAMPLE: 2 sites classified as PEMIC and 1 site classified as R4SBJ

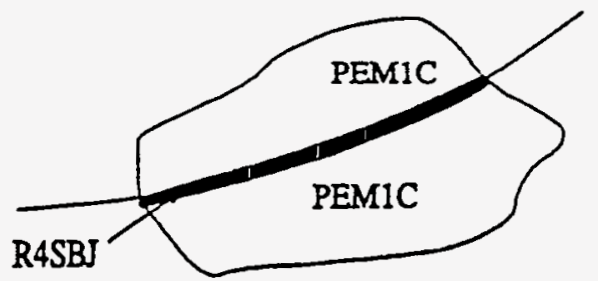

3) Polygon intersected by linear map features and labeled on either sicie was treated as a single site

EXAMPLE: One site classified as PEMIC

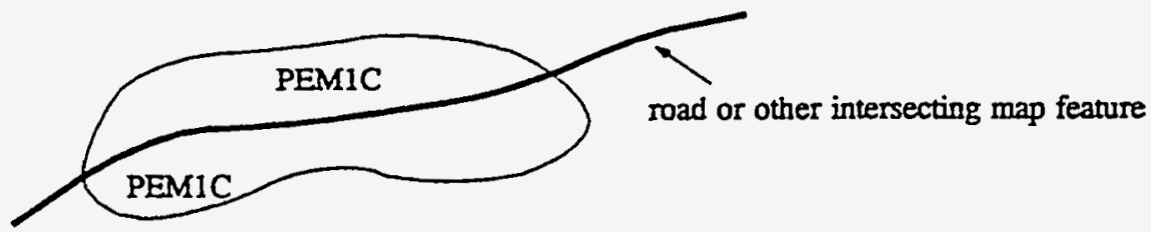

4) Segments along mapped riverine features were each designated as a single sample site

EXAMPLE: 2 sites classified as R4SBI

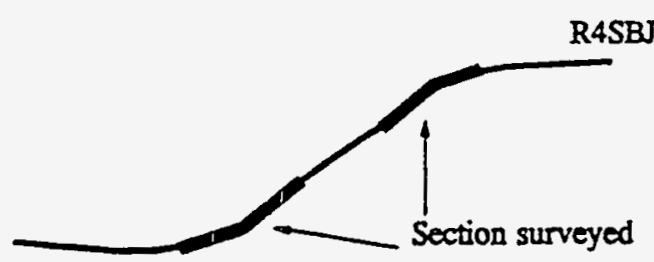

Figure 2. Examples of site definition for polygons and linear features. 
1. Location with respect to existing or proposed facilities - Wetlands located in the immediate vicinity of proposed or existing facilities were included to provide additional information for facility planning, design, and environmental monitoring. Because of logistic problems associated with facility security, three sites inside existing facility fences were excluded from the survey.

2. Schedule and Budget - The number of sites selected was based on an estimate of what could be surveyed within the limits of schedule and budget. Constraints on time were increased by the possible onset of winter weather conditions that would impact helicopter and ground transportation.

3. Total number of sites within each FWS classification - One goal of the survey was to obtain information for each wetland classification found on the INEL, therefore a minimal number of sample sites from each type was desirable to describe the range in variability. Generally, all sites for wetland typess having six or fewer mapped wetlands were included in the survey. Approximately $50 \%$ of the wetlands in each of the remaining classifications were selected for the survey. The resulting number of sample sites for each type is shown on Table 1.

4. Distribution over the entire INEL - Another goal for the survey was to obtain information on wetlands distributed throughout the INEL, therefore site selection included sample sites from each of the quadrangles with mapped wetlands. Sites were selected from the 13 topographical quadrangles in which NWI wetlands were mapped and four unmapped quadrangles.

Information provided by NWI maps, USGS 7.5' topographical maps and high altitude aerial photographs was used to select samples from all 16 FWS and the two special classes. Where separate wetlands of the same classification were grouped in close proximity, one or two sites were subjectively chosen.

5. Distribution of unmapped and unclassified areas - NWI maps for five quadrangles covering the INEL, but drafts were unavailable for this survey. Some areas shown on these quadrangles that appeared to fit the profile of other NWI mapped wetlands on the INEL were included in the survey. A number of potential, but unclassified wetland areas, were identified through review of topographic maps, aerial photographs, and aerial survey. These areas were 
not classified as wetlands by NWI, but have similar characteristics and locations to mapped wetlands. A small sample of these unclassified sites was included to compare with areas that were mapped by the NWI. This effort was included to provide a better understanding of the wetland delineation criteria and characteristics specific to INEL mapped wetlands and the consistency of the NWI maps. 


\section{FIELD SURVEY METHODS}

Wetland characteristics within the perimeters delineated on NWI maps were described in detail for this survey. General information was collected for areas beyond most mapped wetland perimeters (approximately $100 \mathrm{~m}$ ) to obtain a more complete profile of habitat, wildlife use and potential importance. Channel segments with cottonwood (Populus angustifolia), willow (Salix exigua) or other unique habitat along the banks were selected as sampling sites for riverine features (see Figure 2). However, because information collected for riverine wetlands applies primarily to the stream channel, habitats along the banks were described independently. Where NWI maps were unavailable (unclassified and unmapped areas), wetland perimeters were approximated by comparison to similar classified wetlands.

An example of the Wetlands/GIS Field Documentation Form used for this survey and instructions for its completion are given in Appendix A. The form includes primary components of the NWI wetlands assessment forms (Federal Interagency Committee for Wetland Delineation, 1989) combined with information necessary for validation of a vegetation map being developed for the INEL.

A field form was completed for each site. These documentation forms were completed in conjunction with an intuitive controlled intensity level survey (U.S. Forest Service, 1991). This survey is utilized by the U.S. Forest Service to conduct vegetation inventories, identify plant associations, and develop habitat descriptions for threatened and endangered species. The survey consisted of walking areas within wetland perimeters and in the general area to ensure that all vegetation and/or unique habitats were located. This survey methodology is a more detailed adaptation of the NWI routine plant community assessment procedure (Federal Interagency Committee for Wetland Delineation, 1989). It was applied during the field investigation of INEL wetlands to address both routine assessment and EIS requirements. Copies of the data forms completed for this survey are on file with Enviromental Assessment Technologies.

A routine survey of vegetative characteristics including abundance, species (Plummer, et al., 1977), wetland indicator status (Reed, 1986), and areal extent of vegetation was conducted for areas inside mapped wetland perimeters and most surrounding areas. The abundance of each vascular plant 
species occurring on the site was ranked using a four-point scale $(4=$ dominant to $1=$ rare). The scale is a simplification of cover/abundance scales (Mueller-Dombois and Ellenberg, 1974) based on intuitive abundance categories (plant basal coverage) rather than cover-class estimates.

Hydrological information including evidence of past and present water activity, drainage patterns, water marks, drift lines, and vegetation damage due to inundation were collected as part of the routine survey for each site. Information was recorded for both areas inside mapped perimeters and features in the general vicinity that may be important to hydrological characterization, e.g. stream channels.

Information required for extensive soil analyses is also addressed by the field documentation form. However, for this survey, only soil color and a field estimate of soil texture were recorded.

Animal observations, tracks, scat, nests, burrowing, and browsed vegetation were used as indicators of wildlife use. As part of the routine survey, all indicators observed inside wetland perimeters and surrounding areas were recorded. When a positive identification could be made, the species was noted. Relative abundance of sign for each species identified was rated high, moderate or low. Consideration was given to size of the survey area and individual species habit to make a subjective estimate of use.

Presence of archaeological evidence was also used to rate each site as high, moderate, low, or none depending on relative abundance of prehistoric archaeological objects or structures. For this survey, archaeological objects included artifacts (objects with definable shape and characteristics of tools, for instance spear points or scrapers) and flakes (pieces of lithic waste created during the manufacture of stone tools). As part of the routine survey, archaeological evidence observed inside wetland perimeters and surrounding areas was recorded. The size of the area covered by the survey and the density of artifacts and flakes were considered to make a subjective estimate of relative abundance. Each wetland area was ranked as high, moderate, or low with respect to both artifacts and flakes.

Position coordinates for most sites were obtained using a Trimble Navigation Pathfinder Professional Global Positioning System (GPS). To maximize accuracy, field coordinates were 
differentially corrected using files collected by the Community Base Station located at the INEL Research Center (IRC). Where possible, GPS positions at each site were obtained from easily identifiable locations, for instance, the approximate site center, corner or permanent landmark. Separate GPS data forms were completed for each site and site identifiers associated with the wetland field documentation forms were used as filenames for GPS data. The GPS field data collection collection forms are on file with Environmental Assessment Technologies.

Color slides were obtained at each site using a $35 \mathrm{~mm}$ camera fitted with a $50 \mathrm{~mm}$ lens and ASA 64 Kodachrome film. Views facing north, west, south, east and down were taken from the same point as the GPS data. For fenced or water filled areas, GPS readings and photographs were obtained at fence corners, access road intersections, or outlets. Film roll identification and frame numbers for each site were recorded on the field documentation forms. Photographs for each site visited during the survey are archived with Environmental Assessment Technologies.

Access to INEL wetland sites was gained primarily through use of the Department of Energy (DOE) helicopter operated by Protection Technology Idaho (PTI) personnel. Only a few primitive access roads exist through extensive sage and lava areas of the INEL and in many areas, lack of topographical relief and/or landmarks make navigation from the ground difficult. NWI wetland maps, topographical maps and color aerial photos were used extensively to locate and distinguish sites, especially in rough terrain. Without the benefit of helicopter transportation, this survey would have taken substantially more time and funding to complete. 


\section{WETLAND CHARACTERISTICS AND DISTRIBUTION}

A total of 121 sites in $16 \mathrm{NWI}$ and two special categories were surveyed. Field descriptions were completed for 105 of the 121 sites. In addition to the 100 sites planned for the survey, 20 sites were inspected as part of the verification of grouped wetland sites. Where separate wetlands of the same classification were grouped in close proximity, a single site was surveyed and several or all adjacent sites were visited to verify similarity. Mapped NWI wetlands and survey sites are shown in Figure 3.

Permanent and temporary water sources are important components of desert ecosystems (Jones, 1986). Based on this assumption, a subjective ranking of individual sites was compiled to prioritize INEL wetlands with regard to potential ecological importance. A qualitative importance ranking for each site was based on unique habitats or vegetation observed, areal extent, hydrology, observation or signs of wildlife use, plant and animal diversity, disturbance, historical record and archaeological evidence. Sites having vegetation communities dominated by species other than sagebrush (Artemisia spp.) are generally less common on the INEL. As a result, the wetland sites having large areas dominated by basin wildrye (Elymus cinereus), greasewood (Sarcobatus vermiculatus) or winterfat (Ceratoides lanata), for instance, were ranked higher in ecological importance because of their unique characteristics. Sites in close proximity to other mapped wetlands that appeared to be linked as a network were given a higher ranking. Overall evidence of wildlife use was estimated as high, moderate or low based on sign for all species combined. Sites having greater diversity of plant and animal species, and those with substantial archaeological evidence, were ranked higher in ecological importance. Highly disturbed areas (human activities, grazing, etc.) were rated lower than sites retaining apparent natural characteristics. For some areas (e.g. Big Lost River Sinks), wetland attributes including hydrology, vegetation, and soils described in prior INEL studies were used to augment field data for determination of the overall ranking. Each site was individually assessed and assigned a number between 1 and 4, where 1 represents wetlands ranked highest in potential importance and 4 represents sites having no apparent wetland characteristics.

Conditions associated with extended drought and the season in which field investigations were conducted limited the collection of important vegetative and hydrological information, and other information such as wildlife use is not available. This ranking procedure can only be considered a 


\section{WETLANDS OF THE INEL}

(As mapped by the USFWS National Wetlands Inventory)
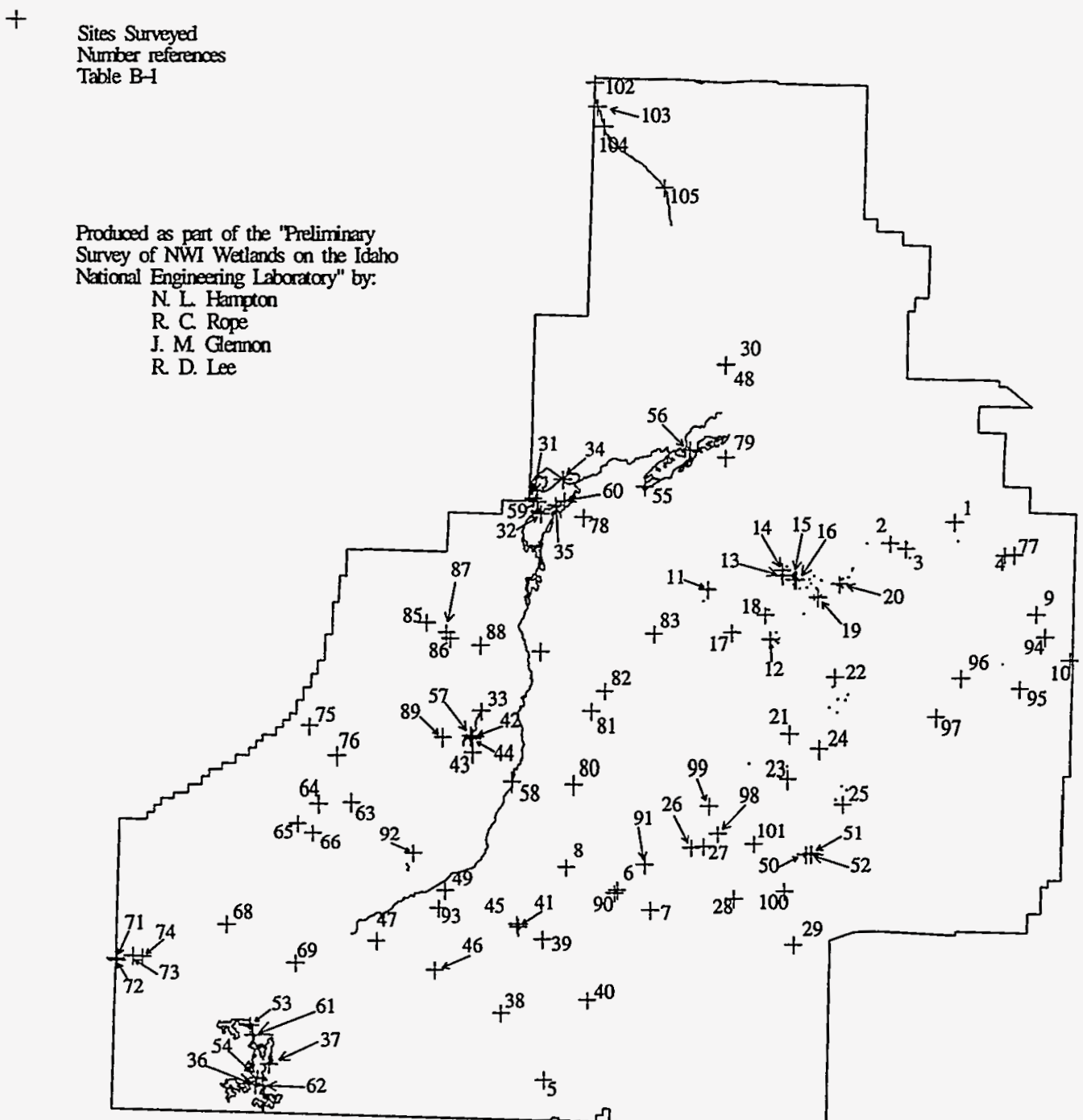

Noxe: This map does not address omission and cormission enors and is not field verified.

Figure 3. Mapped NWI wetlands and surveyed sites. 
subjective estimate of potential importance of each wetland relative to the conditions present during the survey.

Summarized information and rankings for each of the 105 surveyed sites are presented in Appendix B, Table B-1. General characteristics including vegetation, wildlife use, archaeological evidence and rankings for the sixteen NWI wetlands and two special classifications are discussed below. Definitions of the NWI and special classifications are given on Table 1.

\subsection{Palustrine and Lacustrine Wetlands}

\subsubsection{PUSJ Classified Wetlands}

Approximately $70 \%$ of the individual NWI wetlands within INEL boundaries are classified as PUSJ. The distribution of surveyed PUSJ sites is shown on Figure 4. Total area encompassed by PUSJ wetlands is just under 20-ha (50 acres). The smallest PUSJ site is approximately .04-ha (.1 acre) and the largest about 3-ha (7 acres).

Thirty-seven of the 44 surveyed PUSJ wetlands are dry, bare playas with scattered halogeton (Halogeton glomeratus) plants established in mud cracks. Four sites (Figure 4, sites 9, 23-25) are basins containing primarily basin wildrye (Elymus cinereus). Other established vegetation at PUSJ sites was rare. Nearly all sites are surrounded by sagebrush (Artemisia spp.) in some combination with other species including weeds, grasses, greasewood (Sarcobatus vermiculatus), rabbitbrush (Chrysothamnus spp.), or winterfat (Ceratoides lanata). Plant species identified at PUSJ wetlands are listed on Table 2.

Although no water was present at any PUSJ site, their characteristics indicate that water is present during some parts of the year. No obligate or facultative wetland vegetation was observed. Playa soil texture was generally fine (silty clay or silty clay loam) and compacted, with surfaces broken by mud cracks. Many of the sites are surrounded by large areas of dead and dying sagebrush (Artemisia spp.). No rare or endangered species were observed. 


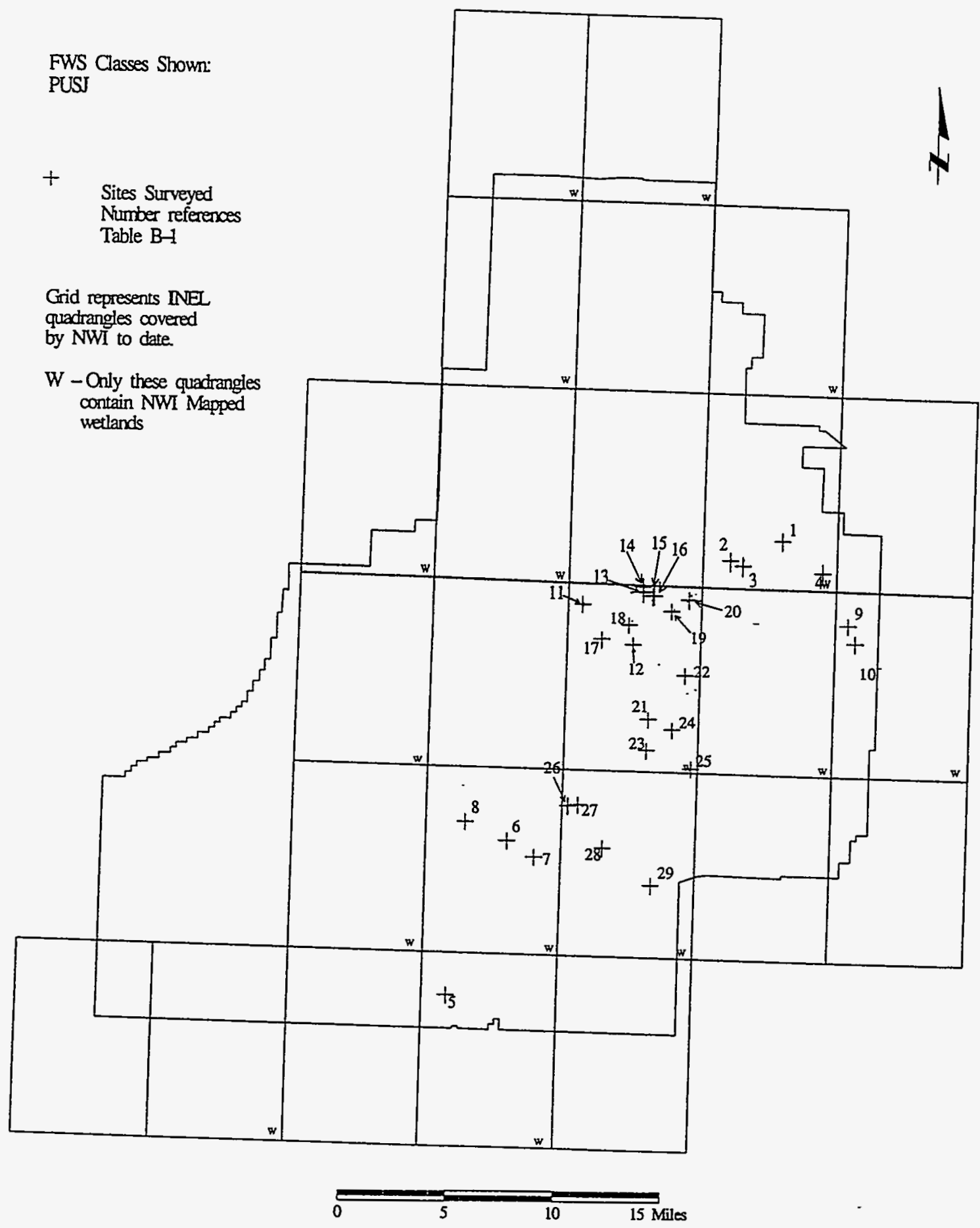

Figure 4. Surveyed PUSJ wetlands of the INEL. 
Table 2. Summary of vegetation observed at sampled PUSJ wetland sites.

\begin{tabular}{lll}
\hline \multicolumn{1}{c}{$\begin{array}{c}\text { WETLAND } \\
\text { CLASSIFICATION }\end{array}$} & \multicolumn{1}{c}{ ON-SITE VEGETATION } & INDICATOR STATUS \\
\hline PUSJ & $\begin{array}{l}\text { Agropyron dasystachyum } \\
\text { Artemisia tridentata kyomingensis } \\
\text { Atriplex nuttallii } \\
\text { Chrysothamnus viscidiflorus } \\
\text { Elymus cinereus } \\
\text { Halogeton glomeratus } \\
\text { Machaeranthera canescens } \\
\text { Opuntia polyacantha } \\
\text { Oryzopsis hymenoides } \\
\text { Phlox hoodii } \\
\text { Poa nevadensis } \\
\text { Salsola kali }\end{array}$ & FACU \\
& $\begin{array}{l}\text { UPL } \\
\text { a Region } 9 \text { wetland indicator status (Reed, 1988) }\end{array}$ & FACU \\
UPL - upland & FACU \\
FACU - facultative upland & FAC - facultative \\
FACW - facultative wetland \\
OBL - obligate wetland \\
A blank indicates that species is not included on the Region 9 list and is therefore considered UPL (Reed, 1988).
\end{tabular}

Evidence of wildlife was present at all PUSJ sites, and, nearly one third of the sites had signs of heavy use. Archaeological evidence was moderate overall, but substantial quantities of material were noted at several individual sites. Ten of 15 PUSJ sites located in the Little Butte NW quadrangle and all three sites in Antelope Butte Quadrangle were ranked high with respect to potential ecological importance (Table B-1). Unique features of these areas include uncommon vegetative composition, interconnected networks of playas, and high evidence of wildlife use. More information would be required to assess wildlife use. Sites of interest should be visited during the growing season and during years with normal precipitation for better information on plant and animal communities. An assessment of seasonal water retention would be required and should include soil data for definitive characterization of these wetlands. More detailed surveys would have to be made to determine the nature and complete extent of the observed archaeological materials.

\subsubsection{L2USJ, PEM1A, PEM1C, PEM1J, and PEMJ Classified Wetlands}

Lacustrine (L2USJ) and palustrine (PEMJ, PEM1J, PEM1A, and PEM1C) classifications cover large portions of the Big Lost River spreading areas and the outflow areas from the Big Lost River sinks. The distribution of these wetlands and location of surveyed sites are shown in Figure 5. 


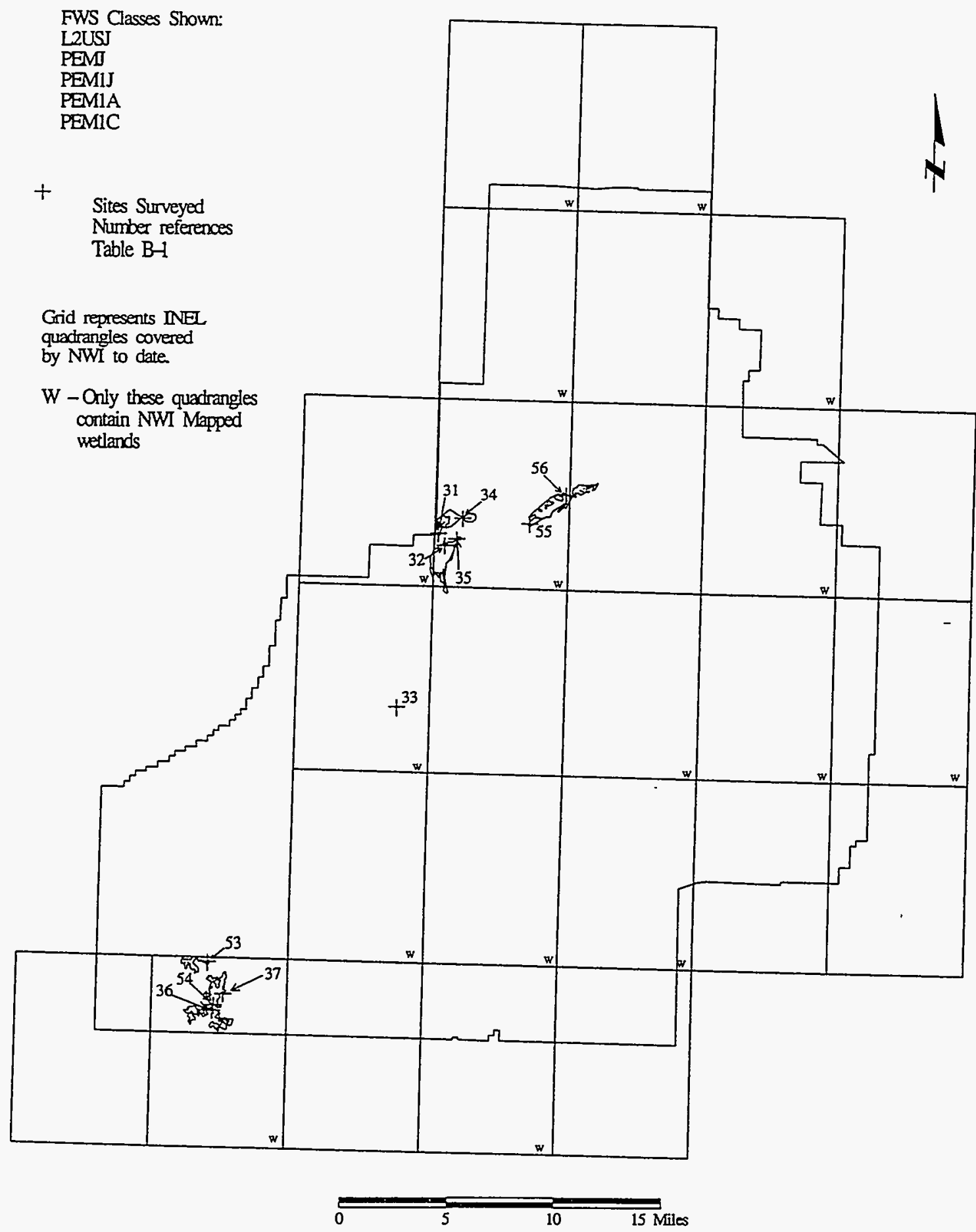

Figure 5. Surveyed palustrine and lacustrine wetland sites of the INEL. 
The largest single area encompassed by L2USJ wetlands is approximately 325 -ha (800 acres). Area totals for PEMJ, PEM1J, PEM1A and PEM1C wetlands are between 160-ha (400 acres) and 290-ha (700 acres). INEL wetlands included in these classifications cover approximately 1417-ha (3500 acres) total.

Wetlands for these five classifications are expansive, with large areas of bare ground and perennial weed cover. Most areas are heavily grazed by cattle. Native perennials are present in small numbers for both PEM1J sites (Figure 5, sites 34, 35) and some native grasses were found among many weed species at the PEM1A site (Figure 5, Site 31). Sagebrush (Artemisia spp.) dominated communities surround both lacustrine and palustrine wetlands for all five classifications. Plant species identified for L2USJ, PEM1A, PEM1C, PEMJ, and PEM1J wetlands are listed on Table 3.

Remains of obligate wetland vegetation [bulrush (Scirpus acutus)] were observed at an outflow area north of NRF (PEM1C) (Figure 5, Site 33), and remains of cattails (Typha latifolia) were found in areas of the Big Lost sinks (PEM1C)(Figure 5, Site 32). However, a combination of extended drought, upstream water diversion and heavy cattle grazing have reduced vegetation in the Big Lost sinks to bare ground and weed cover. Gray sandbar willow (Salix exigua), an obligate wetland species, was identified in the L2USJ areas east of the Big lost sinks (Figure 5, Sites 55, 56), and several facultative wetland species curly dock (Rumex crispus), doorweed (Polygonum aviculare) were also identified at L2USJ, PEM1J and PEM1C sites (Figure 5, Sites 55, 34 and 32, respectively). Soils were generally loose, disturbed and fine (sandy silt). No rare or endangered species were observed.

Low to moderate evidence of wildlife use was observed for all eleven of these sites. Three sites had substantial archaeological evidence (one L2USJ [Figure 5, Site 55], one PEMJ [Figure 5, Site 37] and one PEM1J [Figure 5, Site 34]). Overall, potential ecological importance for wetlands included in these classifications is moderate, however four individual areas demonstrating potential for providing unique habitat have been ranked high.

These areas should be examined under normal moisture conditions. Historical photographs show that extensive areas of obligate wetland vegetation existed in the Big Lost sinks as recently as 
Table 3. Summary of vegetation observed at sampled palustrine and lacustrine wetland sites.

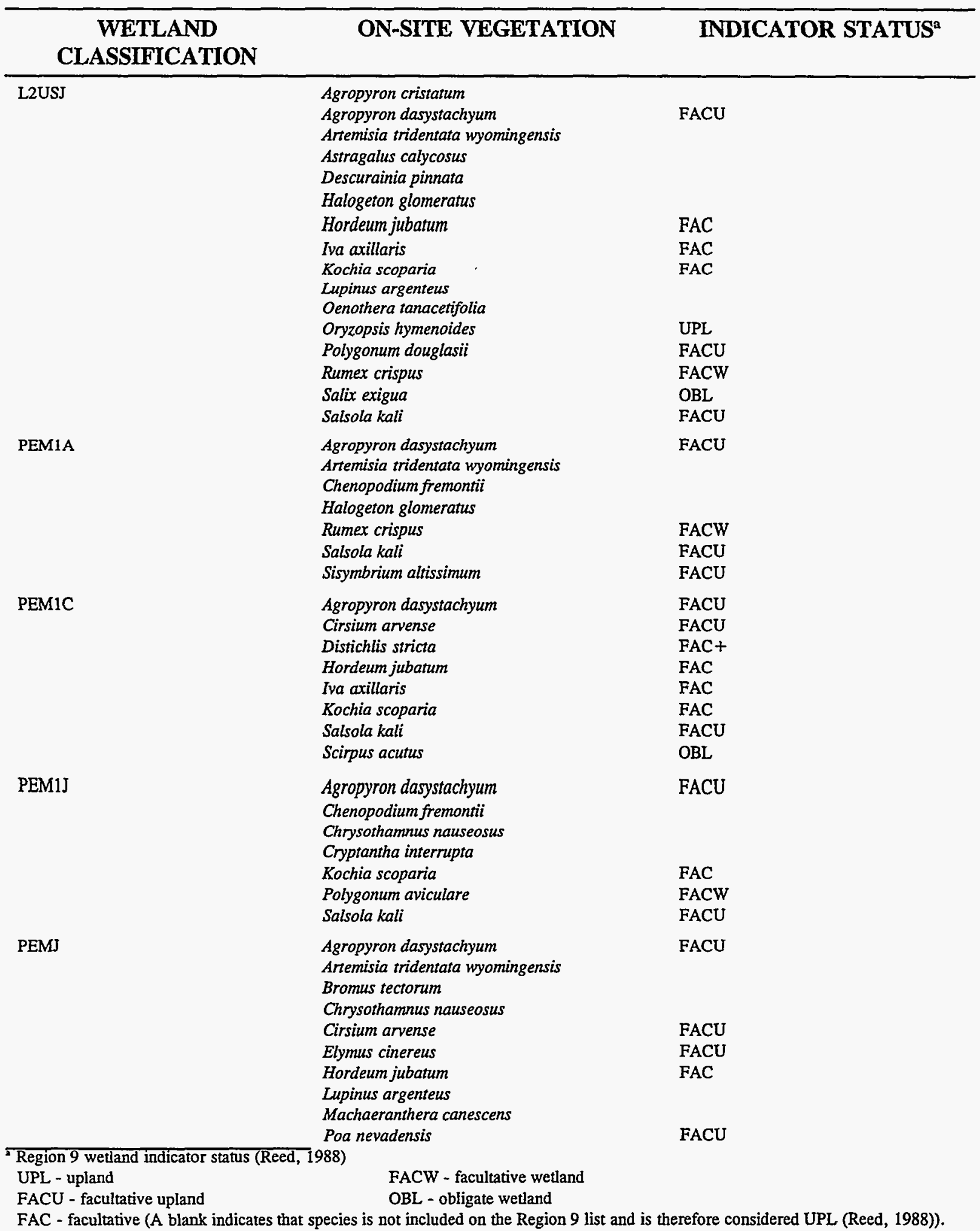


1984. Patterns of wildlife use and information to assess grazing impacts on vegetation and wildlife may be useful for further characterization. The northernmost PEM1A site (Figure 5, Site 31) located in the Big Lost sinks is the only INEL wetland that has been ground-truthed by the FWS for the NWI

\subsection{Riverine Wetlands}

Riverine classifications (R4SBJx, R4SBA, R4SBC, R4SBJ, R20WHx) represent channel features associated with the Big Lost River. The main river channel is mapped as a single R4SBA feature. The distribution of these wetlands and the location of surveyed sites are shown on Figure 6 .

The river channel features classified as R4SBC (Figure 6, Site 59), R4SBJ (Figure 6, Site 60), and R4SBJx (Figure 6, Sites 61,62) are generally scattered with weeds. Extended drought conditions have allowed establishment of sparse vegetation, including perennials from the riparian and upland vegetation, along the Big Lost River (R4SBA) (Figure 6, Site 58). Cottonwood (Populus angustifolia), rose (Rosa woodsii), willow (Salix exigua), chokecherry (Prunus virginiana) and sagebrush (Artemisia tridentata) riparian habitats are common along the southern half of the Big Lost River.

All surveyed riverine wetlands were dry with the exception of the R2OWHx site (Figure 6, Site 57). This site is one of three areas surveyed on the INEL that supports obligate wetlands vegetation. Bulrush (Scirpus acutus) and cattails (Typha latifolia) are maintained at this site by water flow from NRF facility operations. Gray sandbar willow (Salix exigua) was the only additional obligate wetland species identified in the main Big Lost River channel (R4SBA). All plant species identified at sites investigated for these classifications are listed on Table 4.

Light to moderate evidence of wildlife use was observed for all riverine areas. However, in some sections of the river, raptor nests and a number of owls were observed in habitats along the banks. Some sections of channel (R4SBJ) (Figure 6, Site 60) are heavily disturbed by cattle grazing. The archaeological sensitivity of these channels is also very high as evidenced by dense concentrations of surface materials and the erosion of buried archaeological materials from cutbanks. 


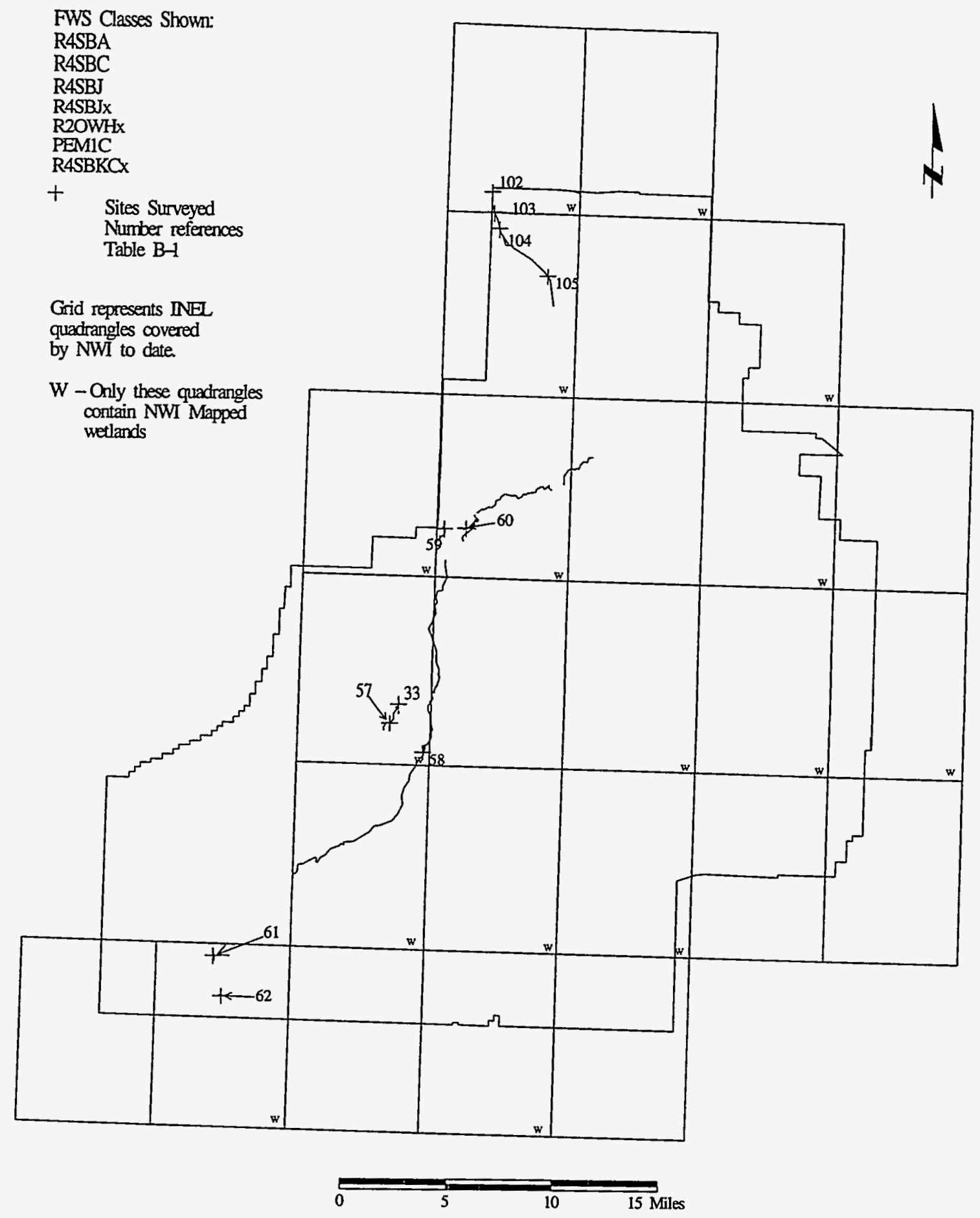

Figure 6. Surveyed riverine wetlands of the INEL. 
Table 4. Summary of vegetation observed at sampled riverine wetland sites.

\begin{tabular}{|c|c|c|}
\hline $\begin{array}{c}\text { WETLAND } \\
\text { CLASSIFICATION }\end{array}$ & ON-SITE VEGETATION & INDICATOR STATUS \\
\hline R20WHx & $\begin{array}{l}\text { Cirsium arvense } \\
\text { Scirpus acutus } \\
\text { Typha latifolia }\end{array}$ & $\begin{array}{l}\text { FACU } \\
\text { OBL } \\
\text { OBL }\end{array}$ \\
\hline R4SBA & $\begin{array}{l}\text { Agropyron caninum } \\
\text { Artemisia tridentata wyomingensis } \\
\text { Astragalus lentiginosus } \\
\text { Chrysothamnus nauseosus } \\
\text { Chrysothamnus viscidiflorus } \\
\text { Euphorbia glyptosperma } \\
\text { Machaeranthera canescens } \\
\text { Melilotus officinalis } \\
\text { Oryzopsis hymenoides } \\
\text { Salix exigua } \\
\text { Salsola kali } \\
\text { Solidago canadensis }\end{array}$ & $\begin{array}{l} \\
\text { FACU } \\
\text { UPL } \\
\text { OBL } \\
\text { FACU } \\
\text { FACU }\end{array}$ \\
\hline R4SBC & $\begin{array}{l}\text { Artemisia tridentata tridentata } \\
\text { Chrysothamnus nauseosus } \\
\text { Iva axillaris } \\
\text { Kochia scoparia } \\
\text { Salsola kali }\end{array}$ & $\begin{array}{l}\text { FAC } \\
\text { FAC } \\
\text { FACU }\end{array}$ \\
\hline R4SBJ & $\begin{array}{l}\text { Agropyron dasystachyum } \\
\text { Chrysothamnus nauseosus } \\
\text { Iva axillaris } \\
\text { Salsola kali }\end{array}$ & $\begin{array}{l}\text { FACU } \\
\text { FAC } \\
\text { FACU }\end{array}$ \\
\hline R4SBJX & $\begin{array}{l}\text { Agropyron cristatum } \\
\text { Agropyron dasystachyum } \\
\text { Artemisia tridentata wyomingensis } \\
\text { Artemisia tripartita } \\
\text { Chaenactis douglasii } \\
\text { Chrysothamnus nauseosus } \\
\text { Chrysothamnus viscidiflorus } \\
\text { Cirsium arvense } \\
\text { Descurainia pinnata } \\
\text { Eriogonum microthecum } \\
\text { Hordeum jubatum } \\
\text { Iva axillaris } \\
\text { Lupinus argenteus } \\
\text { Machaeranthera canescens } \\
\text { Medicago sativa } \\
\text { Oenothera caespitosa } \\
\text { Oryzopsis hymenoides } \\
\text { Salsola kali }\end{array}$ & $\begin{array}{l}\text { FACU } \\
\text { FACU } \\
\text { FAC } \\
\text { FAC }\end{array}$ \\
\hline
\end{tabular}

\footnotetext{
- Region 9 wetland indicator status (Reed, 1988)

UPL - upland

FACU - facultative upland

FAC - facultative

FACW - facultative wetland

OBL - obligate wetland

A blank indicates that species is not included on the Region 9 list and is therefore considered UPL (Reed, 1988).
} 
Potential ecological importance for the Big Lost River (R4SBA) is high, primarily because of the unique and isolated wildlife habitat it provides. Site R2OWHx (Naval Reactor Facility outflow channel) was assigned a moderate ranking because it represents one of three sites on the INEL at which obligate wetland vegetation and water was present.

Because the section of the Big Lost drainage classified as R4SBC is only intermittently flooded, a "J" rather than a "C" designation should be assigned (R4SBJ).

The Birch Creek drainage is a notable riverine area in the northern part of the INEL. Several sites in the drainage were investigated during this survey (Figure 8, Sites 102-105). The creek system contains areas with important riparian communities including of cottonwoods (Populus spp.), willow (Salix spp.), birch (Betula occidentalis), chokecherry (Prunus virginiana) and wild rose (Rosa woodsii). This is a potentially important area to wildlife, particularly when water is present. Plant species identified at these sites are listed on Table 4.

\subsection{Manmade Wetlands}

Manmade wetlands on the INEL include industrial waste or sewage treatment ponds (PAB4Hx, POWHx, PUSCx, PUSCrx), excavated channels (R2OWHx, R4SBJx, R4SBKCx) and borrow or gravel pits (PUSC) associated with INEL facilities. The distribution of the sites visited during this survey is shown in Figure 7. With the exception of several POWHx ponds and channel segments (" $R$ " identifiers), these wetlands are generally less than .8-ha ( 2 acres) in size and are indistinguishable at the scale shown on Figure 7.

Most waste ponds are surrounded by gravel berms and some are lined. Water sources for these sites are sustained as part of facility operations. Most have only weed species growing around the edges. An exception is the industrial waste pond northwest of Argonne, where water flow maintained by facility operations supports obligate wetland vegetation including bulrush (Scirpus acutus) and cattails (Typha latifolia). The obligate wetland species, gray sandbar willow (Salix exigua) was observed at the waste area south of ARA (PUSCrx [Figure 7, Site 40]). The single PUSC site (Figure 7, Site 38) is an excavated borrow pit with weeds and crested wheatgrass (Agropyron cristatum). Minor facultative wetland components observed at POWHx (Figure 7, Site 


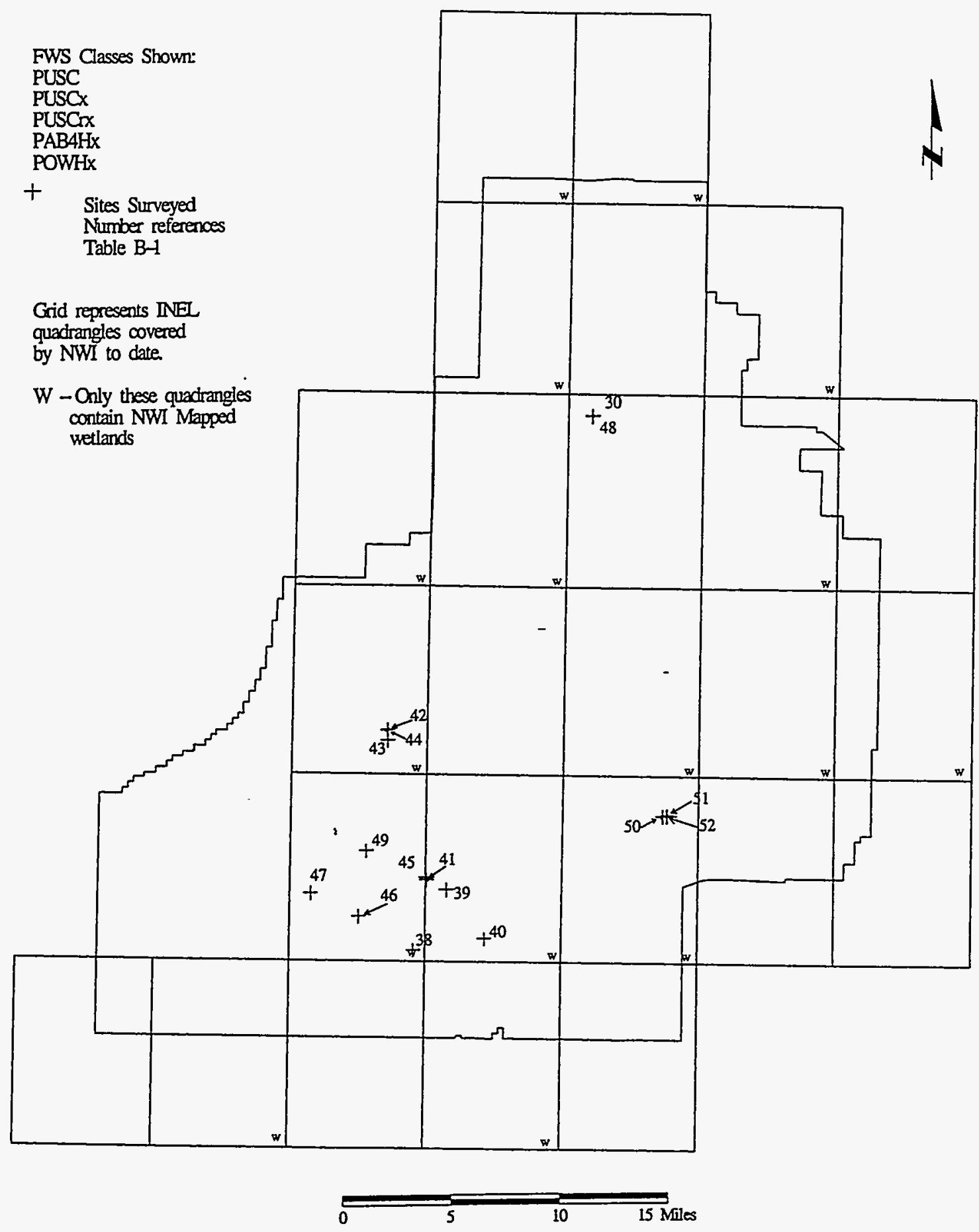

Figure 7. Surveyed manmade wetlands of the INEL. 
48) and PAB4Hx (Figure 7, Site 30) sites include barnyard grass (Echinochloa crusgalli), doorweed (Polygonum aviculare) and curly dock (Rumex crispus). Plant species identified at these sites are listed on Table 5.

The only standing or running water observed at INEL NWI wetlands during this survey was contained in industrial waste ponds or outflow channels associated with facility operations [POWHX and R2OWHx (see section 4.3)]. Evidence of wildlife use for these wetlands was low, however the open water may be of importance to waterfowl in spring and fall. No archaeological evidence was observed at any of these surveyed sites, probably due to the high degree of localized ground disturbance. No threatened or endangered species were observed. Although these areas rank lower in potential ecological importance, they retain importance in relation to facility planning and operations.

Because the single PUSC wetland is excavated, the classification should include an " $x$ " modifier (PUSCx). Six of the eleven POWHx sites have gravel substrates and should include an " $r$ " modifiers (POWHrx). The single wetland classified as PUSCx is a waste pond. Because the pond has standing water, a gravel bed and a liner, an "OW" designation and " $r$ " modifier should be added (POWHrx). Three sites were apparently mis-classified as POWHx. Two areas of dark rock were mistaken for open water on the aerial photos, and one area of sagebrush near a berm had no observable features to support water collection. Of eleven POWHx sites surveyed, six are waste ponds and have gravel substrates. These should include an " $r$ " modifier (POWHrx). One site is a former waste pond that has been capped with concrete. The former waste pond for the LOFT project is classified as PAB4HX. Because the pond has an artificial gravel substrate, an " $r$ " modifier should be included (PAB4Hrx).

\subsection{Wetland Areas in Unmapped Quadrangles}

The 14 unmapped sites (UNMAP) included in this survey are located in seven quadrangles for which NWI maps have not been completed by the FWS. These maps cover the westernmost areas of the INEL. The sites visited include riverine classifications along the Big Lost River, as well as sites that are similar to the PUSJ sites that were investigated in other areas of the INEL. Unmapped riverine sites were similar to the R4SBA sites described in Section 4.1.3. The remaining sites were 
Table 5. Summary of vegetation observed at sampled manmade wetland sites.

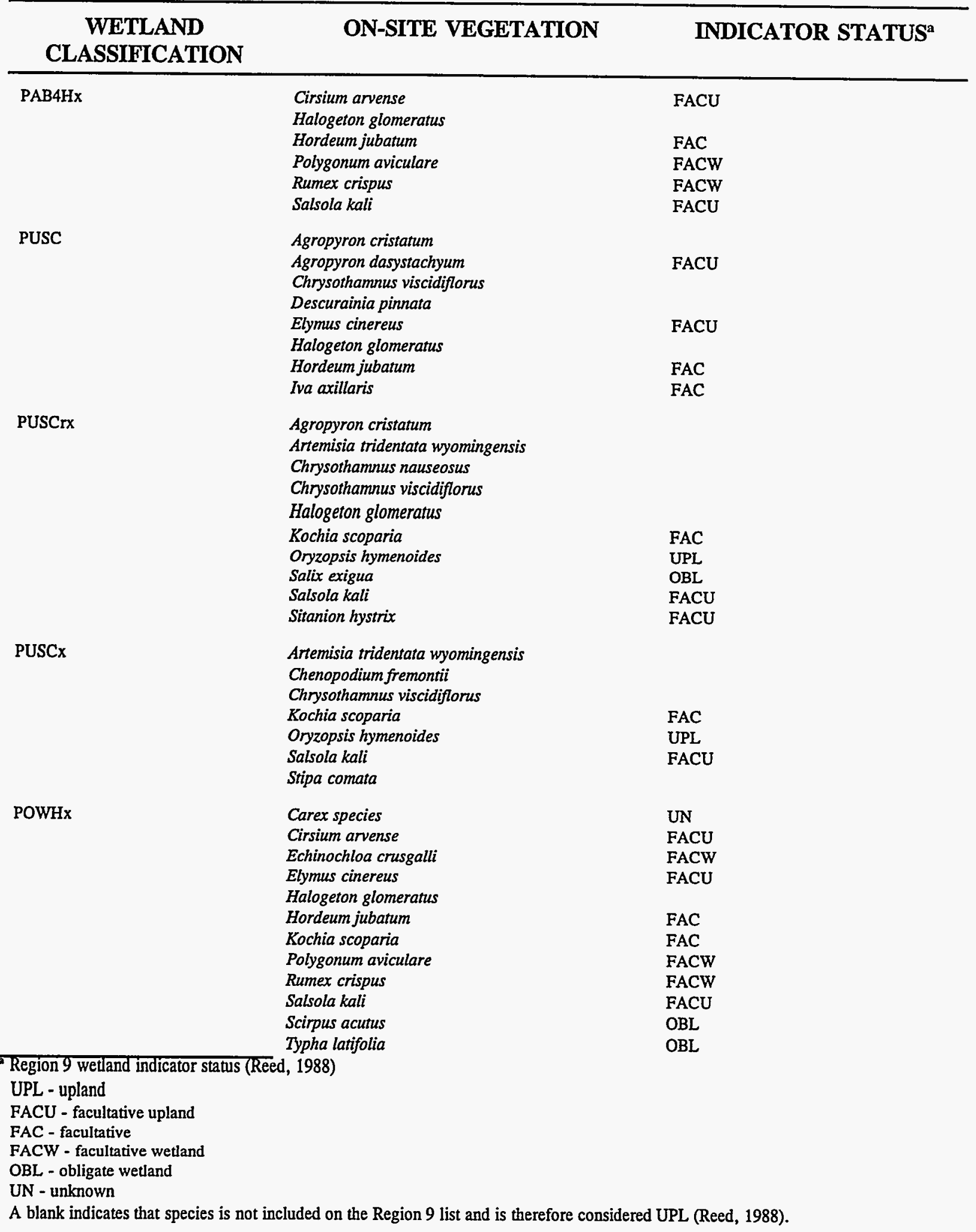


similar in most respects to PUSJ sites described in Section 4.1.1, except that playa areas dominated by basin wildrye (Elymus cinereus) were more common. Plant species identified at unmapped sites are listed on Table 6. The unmapped sites visited for the survey are included on Figure 8.

Unmapped INEL sites visited during this survey should be compared to what is actually included on the forthcoming NWI maps.

\subsection{Unclassified Areas}

Twenty-nine unclassified areas (UNCLASS) on the INEL were included as part of this survey. Non-riverine sites in this classification were similar in all respects to those classified as PUSJ (Section 4.1.1). Most sites were bare playas or basins dominated by basin wildrye (Elymus spp.), however, disturbed areas with numerous weedy species were also included. Some unclassified areas had substantial signs of wildlife use and archaeological evidence. All areas appeared to retain water for some duration during normal precipitation years. A number of these areas are represented as intermittent water (blue) on the USGS 7.5' topographical maps covered by the NWI, however they were not selected for NWI classification. The unclassified sites surveyed are included on Figure 8. Plant species identified at unclassified sites are listed on Table 7.

The status of these areas should be reviewed in cooperation with the FWS and further studies would be needed to determine their relative ecological importance. 
Table 6. Summary of vegetation observed at sampled unmapped wetland sites.

\begin{tabular}{|c|c|c|}
\hline $\begin{array}{c}\text { WETLAND } \\
\text { CLASSIFICATION }\end{array}$ & ON-SITE VEGETATION & INDICATOR STATUS ${ }^{a}$ \\
\hline UNMAP & $\begin{array}{l}\text { Achillea millefolium } \\
\text { Agropyron caninum } \\
\text { Agropyron dasystachyum } \\
\text { Artemisia dracunculus } \\
\text { Artemisia ludoviciana } \\
\text { Artemisia tridentata tridentata } \\
\text { Artemisia tridentata wyomingensis } \\
\text { Artemisia tripartita } \\
\text { Bromus tectorum } \\
\text { Chrysothamnus nauseosus } \\
\text { Chrysothamnus viscidiflorus } \\
\text { Cirsium arvense } \\
\text { Elymus cinereus } \\
\text { Erigeron pumilus } \\
\text { Iva axillaris } \\
\text { Machaeranthera canescens } \\
\text { Medicago lupulina } \\
\text { Opuntia polyacantha } \\
\text { Orobanche fasciculata } \\
\text { Oryzopsis hymenoides } \\
\text { Populus angustifolia } \\
\text { Prunus virginiana } \\
\text { Ribes aureum } \\
\text { Rumex crispus } \\
\text { Salsola kali } \\
\text { Solidago canadensis } \\
\text { Sphaeralcea munroana } \\
\text { Urtica dioica }\end{array}$ & $\begin{array}{l}\text { FACU } \\
\text { FACU } \\
\text { FAC } \\
\text { FAC } \\
\\
\text { UPL } \\
\text { FACW } \\
\text { FACU } \\
\text { FAC } \\
\text { FACW } \\
\text { FACU } \\
\text { FACU } \\
\text { FAC+ }\end{array}$ \\
\hline
\end{tabular}

- Region 9 wetland indicator status (Reed, 1988)

UPL - upland

FACU - facultative upland

FAC - facultative

FACW - facultative wetland

$O B L$ - obligate wetland

A blank indicates that species is not included on the Region 9 list and is therefore considered UPL (Reed, 1988). 


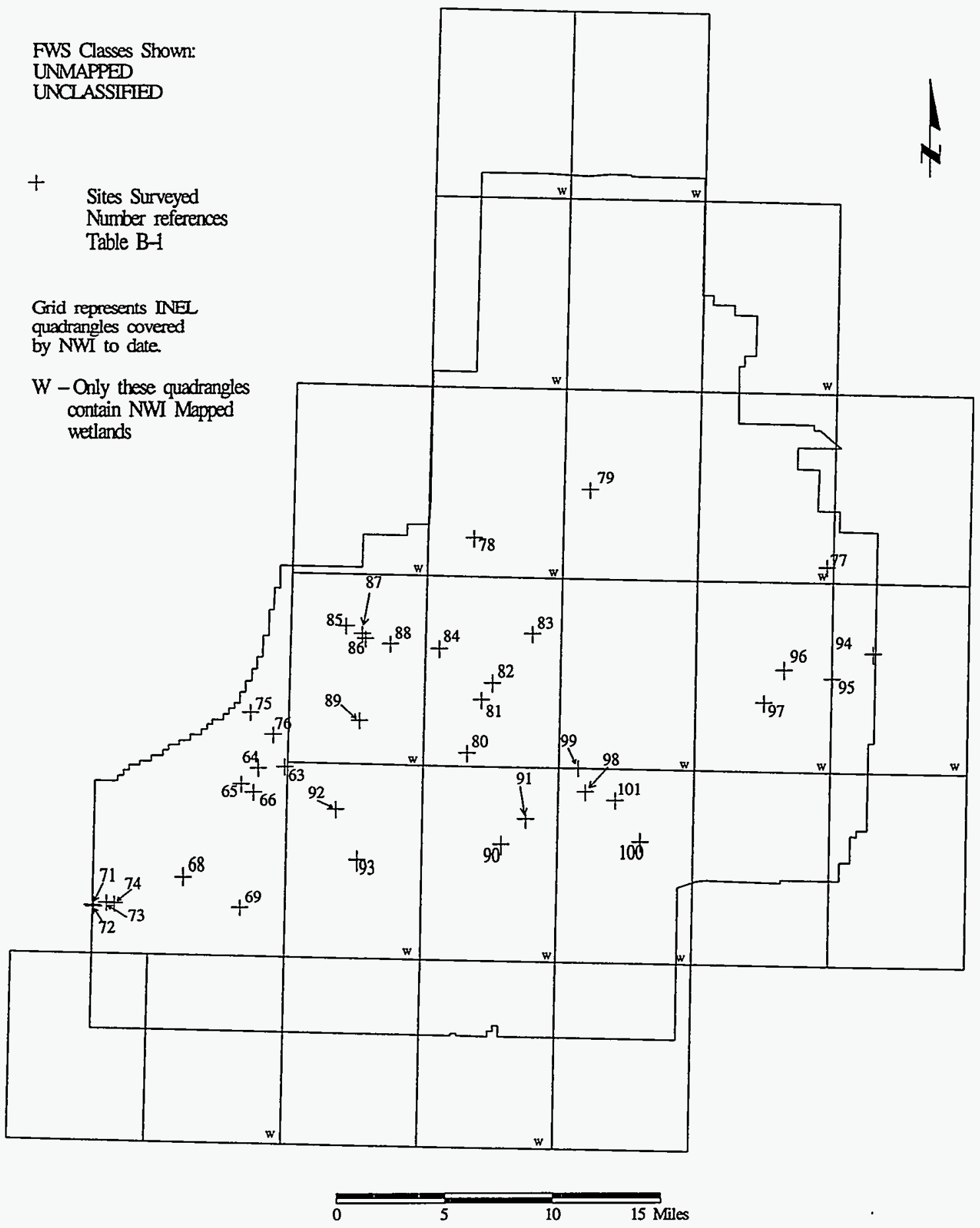

Figure 8. Surveyed unmapped and unclassified areas on the INEL. 
Table 7. Summary of vegetation observed at sampled unclassified wetland sites.

\begin{tabular}{|c|c|c|}
\hline $\begin{array}{c}\text { WETLAND } \\
\text { CLASSIFICATION }\end{array}$ & ON-SITE VEGETATION & INDICATOR STATUS ${ }^{a}$ \\
\hline \multirow[t]{47}{*}{ UNCLASS } & Agropyron spicatum & \\
\hline & Arctium minus & \\
\hline & Artemisia ludoviciana & \\
\hline & Artemisia nova & \\
\hline & Artemisia tridentata tridentata & \\
\hline & Artemisia tridentata wyomingensis & \\
\hline & Asclepias speciosa & FAC \\
\hline & Atriplex canescens & \\
\hline & Atriplex nuttallii & \\
\hline & Betula occidentalis & FACW \\
\hline & Bromus japonicus & FACU \\
\hline & Bromus tectorum & \\
\hline & Carex species & UN \\
\hline & Chaenactis douglasii & \\
\hline & Chenopodium fremontii & \\
\hline & Chrysothamnus nauseosus & \\
\hline & Chrysothamnus viscidiflorus & \\
\hline & Cirsium arvense & FACU \\
\hline & Elymus cinereus & FACU \\
\hline & Eriogonum microthecum & \\
\hline & Euphorbia glyptosperma & \\
\hline & Gutierrezia sarothrae & \\
\hline & Halogeton glomeratus & \\
\hline & Hordeum jubatum & FAC \\
\hline & Hyocyamus niger & \\
\hline & Juncus species & \\
\hline & Kochia scoparia & FAC \\
\hline & Lygodesmia spinosa & \\
\hline & Machaeranthera canescens & \\
\hline & Oenothera tanacetifolia & \\
\hline & Opuntia polyacantha & \\
\hline & Oryzopsis hymenoides & UPL \\
\hline & Poa sandbergii & \\
\hline & Populus angustifolia & FACW \\
\hline & Populus trichocarpa & FAC \\
\hline & Prunus virginiana & FACU \\
\hline & Ribes aureum & FAC \\
\hline & Rosa woodsii & FACU \\
\hline & Rumex crispus & FACW \\
\hline & Salix exigua & OBL \\
\hline & Salsola kali & FACU \\
\hline & Scirpus maritimus & \\
\hline & Sisymbrium altissimum & FACU \\
\hline & Sitanion hystrix & FACU \\
\hline & Solanum triflorum & \\
\hline & Sphaeralcea munroana & \\
\hline & Urtica dioica & FAC + \\
\hline
\end{tabular}

* Region 9 wetland indicator status (Reed, 1988)

UPL - upland

FAC - facultative

FACU - facultative upland

OBL - Obligate wetland

FACW - Facultative wetland

UN - Unknown

A blank indicates that species is not listed on the Region 9 list and is therefore considered UPL (Reed, 1988). 


\section{SURVEY LIMITATIONS}

\subsection{Vegetative Assessment}

Conditions associated with extended drought and the season in which field investigations were conducted significantly limited the analysis of vegetative communities for this survey. General characteristics were identified, but some of the specific vegetative associates necessary for assessing impacts on the site were not present. Historically, the state sensitive species, oxytheca (Oxytheca dendroidea) has been observed in habitats near several of the identified wetlands sites (Cholewa and Henderson, 1984). However, this annual species was not observed during this survey. Although common perennial plant species and most of the annual species were found and identified, rarer species generally bloom in spring and early summer. Detection of these species was more difficult because germination for some annual species has been reduced or eliminated by drought. A future survey for oxytheca should be conducted to definitively assess its status and distribution in relation to INEL wetlands. A complete analysis of vegetation communities and their spatial and ecological elationship to INEL wetlands, as well as soil characterization for these sites, would be necessary for a more comprehensive and site-wide perspective of the importance of wetlands to the INEL ecosystem. A list of plant species identified at wetland sites during this survey is given in Appendix C.

\subsection{Hydrological Assessment}

Investigation of seasonal water cycles for INEL wetlands is crucial to understanding the importance of these areas as wildlife habitat. Precipitation and other weather information should be evaluated to investigate moisture conditions and provide an assessment of how long playas and other INEL wetlands hold water during normal and drought years. Analysis of historic wet cycles, aerial photographs, and existing ecological data for these periods could provide a better understanding of the ecological importance of these wetlands.

Differences exist between aerial photographs used for the NWI classification (1980 or 1984

depending on the USGS quadrangle) and those used for this survey (1991). The NWI photos were 
unavailable for use during this survey, but should be obtained to compare to 1991 photos. The time of year when the NWI mapping photos were taken reflects hydrologic conditions of the specific year and season. Photos from periods representing wet and dry cycles are available and could be compared to clarify omission or inclusion of particular sites.

When 7.5' USGS topographic data for the INEL becomes available, GIS analysis of individual basins could be used to determine drainage patterns and areal extent of the basins. This analysis would help to evaluate the hydrologic properties of the wetlands and surrounding areas.

\subsection{Wildlife Use}

For this survey, wildlife use of wetland habitats was estimated from sign and fauna observed on site. However, use by species leaving no sign is not reflected in this estimate. Waterfowl or amphibians may utilize some areas during periods when standing water is present. Infrequent visits by smaller species (reptiles, for instance) are undetected. Temporal patterns in wildlife use are also not reflected by information gathered during this survey. Some areas may receive heavy use for very short periods and may be of lower importance than wetlands used at a constant, lesser rate. Comprehensive studies of the use of wetland areas by individual animal species is necessary to evaluate the relative importance of these habitats to INEL wildlife.

Substantial multidisciplinary information is required to determine the importance of wetlands to the INEL ecosystem. Definitive studies are needed to determine the areal extent, temporal duration and periodicity of wetlands, seasonal patterns of use, and relative importance of individual sites to particular plant and animal species. These studies should address the distributional aspects associated with INEL wetlands, as well as their long-term importance through varying climatic cycles. Wetlands located on the INEL may also be important in relation to wildife refuge systems north (Camas, Market Lake, Mud Lake) and south (Salt Lake system, American Falls) of the INEL.

\subsection{Archaeological and Paleoecological Assessment}

Presence of archaeological evidence at wetland areas is important to INEL planning and facility development and the EIS. However, none of the archaeological resources observed during the 
wetlands survey were formally recorded and all will require systematic archaeological survey to determine their historic or prehistoric significance. Further study of the observed archaeological evidence could provide important information on the role of identified wetlands in the economics of prehistoric hunter-gatherers and could thus provide additional clues regarding the ecological importance of these areas.

Sedimentological and geochemical analyses in combination with microplaeontological studies could provide information on the historic, spatial and temporal characteristics of wetlands on the INEL. Aquatic microfossils (diatoms, ostracodes, algal spores), especially from the larger palustrine and lacustrine areas, together with terrestrial pollen and phytoliths could serve as paleoenvironmental indicators (effective moisture regimes, presence, persistence, water depths, and temperatures).

Organic materials, such as bones and plant fossils, from sediments, archaeological and paleontological sites, could help provide a chronological framework (e.g., ${ }^{14} \mathrm{C}$ dating) and information about past ecological conditions at and near the wetlands (Miller, 1993).

Given the current concerns about climate change, areas with the potential to support wetland species if average precipitation increases in this area should be considered a potential, valuable resource. These areas should be identified, mapped, and evaluated regarding their wetter potential.

\subsection{Soil Assessment}

Two of the three primary components of wetland characterization (hydrology and vegetation) were addressed during this survey. Soil color and texture were obtained for each site, however soil sampling and analysis was beyond the scope of this survey. Although some sites meet criteria for vegetation and/or hydrology as applied by the FWS, others would require soil analyses for definitive wetland characterization (Federal Interagency Committee for Wetland Delineation, 1989). NRCS soil survey maps for the INEL are incomplete. A map of INEL soils, produced by McBride et al., 1968, is of insufficient detail to be utilized for the wetland survey. Since the completion of this survey, an updated soil map for the INEL has been produced (Olson and Jeppeson, 1993), however, this map is also too coarse to provide the resolution necessary for the wetland survey. A comprehensive evaluation to assess potential impacts should include soil characterization. 


\subsection{Wetland Classification}

Minor discrepancies in NWI classification were identified and 3 sites were apparently misidentified as open water (see classification POWHx, section 4.1.2). Problems associated with inconsistent classification dealt primarily with modifiers differentiating natural and manmade features. Because of the margin of error inherent in the interpretation of high altitude aerial photographs, the NWI states that maps should not necessarily be considered conclusive and solicits additions or corrections (FWS, 1990). INEL and FWS NWI personnel should work closely together to address these inconsistencies and to review classification status of INEL wetlands. A process to address these issues should be established. This will improve National Environmental Policy Act (NEPA) documentation, land use planning and facility development on the INEL.

In a number of cases, areas with nearly identical characteristics and located in close proximity to classified sites were excluded by the NWI. USGS topographical maps are consulted during the development of NWI maps (FWS 1990). However, a number of areas on the INEL represented as intermittent water (blue) on the topographical maps were not selected for NWI classification (this is addressed on page 10 of USFWS 1990). All topographical maps for the INEL were reviewed and these areas identified. Several of the areas were added to the UNCLASS category to be investigated as part of this survey. Ultimately, one of the sites excluded from NWI classification was one of only three sites on the INEL in which wetland vegetation was present. In contrast, a number of tiny playas with no proximity to drainages or vegetation other than sagebrush were mapped as wetlands. Because of these inconsistencies, NWI maps should be used in conjunction with aerial photos and current topographical maps.

Wetlands classified as PUSJ are the most common on the INEL. In some cases as many as seven sites have been classified within a 500 square meter area. In several areas where numerous sites have been delineated on NWI maps, ground inspection has shown a series of sites connected by small channels and can be interpreted as a large, interconnected unit. These channels are on the same elevational grade and have the same soil and vegetative characteristics. High altitude photo resolution is not fine enough to recognize small ( 1 to $10 \mathrm{~m}$ ) channels and interspaces between vegetation. Incorporation of individual sites into a single, larger network may be warranted for some areas. 
NWI maps for the unmapped quadrangles on the INEL will be completed in the future.

Unmapped INEL sites visited during this survey should be compared to what is actually included on the forthcoming NWI maps. 


\section{CONCLUSIONS}

A preliminary survey of NWI wetlands on the INEL was conducted to a) examine their general characteristics and status, b) to provide an evaluation of relative ecological importance, c) identify additional information needed to complete ecological characterization of important INEL wetlands, and d) to identify high priority wetland areas on the INEL. The purpose of the survey was to provide information to support the preparation of the Environmental Restoration and Waste Management (ER\&WM) Environmental Impact Statement (EIS). The survey was not meant to delineate wetland areas or serve as an accuracy assessment of NWI wetland maps.

INEL wetlands investigated during this survey were identified and delineated by the FWS NWI prior to implementation of the Federal Manual for Identifying and Delineating Wetlands (1989). INEL sites for which wetland vegetation and/or wetland hydrology criteria can be confirmed fulfill the FWS wetland criteria requirement. However, assessment with regard to EPA/COE three wetland criteria requirement can not be made for these sites without confirmation of hydric soils. Conditions associated with extended drought and the season in which field investigations were conducted limited the analysis of hydrological characteristics and vegetative communities, making verification of wetland status for most surveyed sites unfeasible.

Two NWI classified sites on the INEL, the Argonne industrial waste pond (POWHx, Table B-1 site 50), and the outflow channel north of NRF (R2WOHx, Table B-1 site 57), were found to have obligate wetland vegetation growing in areas of standing water. Both sites are under one acre in size and water is sustained by facility operations. The Argonne industrial waste pond is an unlined, excavated depression north of the main facility. The pond is dominated by cattails (Typha latifolia) and bulrush (Scirpus acutus). The NRF outflow channel contains dominant obligate vegetation including bulrush (Scirpus acutus) and cattails (Typha latifolia). These and other facility sustained ponds represent the only water sources maintained nearly year-round, and are not significantly affected by drought.

The role of permanent water sources in an arid environment such as the INEL is unclear, however, it can be speculated to be significant to wildlife. A study by Howe (1986) showed the 
Argonne pond was more heavily used by mourning doves (Zenaida macroura) than were other sites in the study. Halford et al., 1976, and Halford and Millard 1978 report the use of the TRA leaching pond complex by migrating waterfowl and numerous other birds, mammals and reptiles. Mule deer (Odocoileus hemionus) were observed at the pond during the survey and bats are known to utilize manmade open-water impoundments on the INEL, especially in dry seasons. Threats and stresses associated with these sites include the possibility of the spread of contamination to wildlife and humans and reduced or discontinued water discharges. These wetlands meet the FWS criteria for both vegetation and hydrology, however, their artificial nature may make them subject to additional interpretive criteria (Federal Committee for Delineating Wetlands, 1989). These wetlands provide important wetland habitat for INEL flora and fauna and should be considered in any INEL activities that may impact them.

The most prominent INEL feature exhibiting wetland characteristics is the Big Lost River drainage. Although dry, the Big Lost River channel and sinks display relict wetland characteristics and sufficient historical evidence is available to support acceptance of NWI classification status. However, because of their intermittent nature, historic disturbance and upstream water management activities, sections of the Big Lost River drainage may be subject to additional interpretative criteria for hydrologic characterization (Federal Committee for Wetlands Delineation, 1989).

The main river channel has been classified by the FWS as a riverine, intermittent, temporarily flooded streambed (R4SBA) from north of Highway 26 to where the channel becomes braided and widens into the sinks area (see Figure 8). Survey data for sections of the Big Lost River are summarized on Table B-1, sites 58,60, and 70. The mapped channel section is characterized by riparian features and obligate wetland vegetation including cottonwood (Populus spp.) and willow (Salix spp.). The streambed was dry when this survey was conducted, however, streamflows for the Big Lost drainage within INEL boundaries are gauged have been summarized for the years 1965 1987 (Bennett, 1990).

NWI Maps for the river channel from the west INEL boundary to where it crosses Highway 26 have not been completed by the FWS, however attributes of this section were surveyed and found to be similar to NWI mapped channel segments (see Table B-1, sites 71-74). A narrow basalt canyon at the west boundary of this river section is unique to the INEL. The entire river section south of 
Highway 26 supports more dense and diverse vegetation than do northern sections of the river. The river provides important wildlife habitat along most of its length. The habitat is enhanced by its isolation from development and agricultural activity. Aquatic communities including rainbow trout (Salmo gairdneri) and brook trout (Salvelinus fontinalis), are supported when flow is sustained (Overton, 1977). Cottonwoods (Populus spp.) along the banks are prime raptor nesting sites. Numerous nests were observed during survey, and several owls (great horned [Bubo virginianus], long earred [Asio otus]) were sighted. Riparian habitats are also important to other species including birds, rabbits, mule deer (Odocoiles hemionus), pronghorn (Antilocapra americana), coyotes (Canis latrans), bobcats (Lynx rufus), and other species. The river has higher potential than most INEL wetland areas for presence of endangered bird species including bald eagles (Haliaeetus leucocephalus). Archaeological evidence is common along the entire length of the Big Lost River. Stressors resulting from both INEL and offsite activities include dewatering of the river channel through diversion of flows for INEL flood control, agricultural demand and upstream dam operations. Erosion of channel banks from grazing and vehicle traffic on roads crossing the empty channel is evident near the spreading area and several sections north of Highway 26. Siting of future INEL facilities or other construction projects (except roads) in close proximity to the river is unlikely due to the potential for flooding. This area of the river provides important habitat and archaeological evidence and may be sensitive for INEL activities.

The terminus of the Big Lost drainage is formed by four large NWI mapped wetland areas (Figure 9). The PEM1A, PEM1C, and PEM1J classifications represent 75 percent of the total NWI mapped acreage on the INEL. These are classified by the NWI as palustrine areas exhibiting persistent emergent vegetation and temporary flooding (A), seasonal flooding (C) or intermittent flooding (J). The classification of the PEM1A site just northwest of the sinks (Table B-1, site 31) has been field verified by the FWS as part of the NWI. The existence of hydric soils in this area is confirmed by a paleological investigation conducted by Bright and Davis (1982) on peat deposits in the eastern edge of this area, and presence of Blackfoot soils having hydric characteristics (Olson and Jeppeson, 1993). A second PEM1A site further south was not investigated during this survey. All areas in and around the sinks were dry when surveyed, however remains of one obligate wetland species (cattails [Typha latifolia]), as well as snail shells (species unknown) were observed in the large PEM1C area (Table B-1, site 32) south of the ponds (see Figure 9). 
The easternmost pond area (playa 1) was also surveyed (Table B-1, site 34). Historical streamflow records collected at USGS gauging stations show that between 1921 and 1965, water reached the ponds 12 times in 45 years and 11 of 22 years between 1965 and 1987 (Bennett, 1990). These areas also accumulate spring runoff from surrounding areas of higher elevation, however the duration and extent of saturation is unavailable. Historic INEL photographs show expansive areas dominated by cattails (Typha latifolia) in and around the ponds. These wetland areas are disturbed by intensive grazing and aggravated by drought. As a result, extensive invasion by exotic weed species has occurred.

Drought conditions and upstream water diversions result in periodic dewatering of the Big Lost River in summer and winter and prevent sustained flow from reaching these areas. These areas are primarily used by cattle, however elk (Cervus canadensis), sage grouse (Centrocercus urophasianus) and black-tailedjack rabbit (Lepus californicus) sign were observed. The sinks represent one of two areas on the INEL in which the presence of the Great Basin spadefoot toad (Scaphiopus intermontanus) has been recorded. The proximity of this area to the mountains north of the sinks provides a corridor to and from summer range for larger animals. However, the area currently provides little cover for small animals due to grazing activities.

Archaeological evidence was observed in the east pond (Table B-1, site 34), however none was found at other surveyed sites. These areas are vast in comparison to other wetlands included in this survey and it is likely that searches over larger sections of the sinks would reveal further archaeological indicators. The Big Lost sink areas have high potential ecological importance based on their ability to sustain large expanses of wetland vegetation. The presence of this type of habitat is unique on the INEL and can provide important habitat for birds and mammals, including those less common to the dominant INEL vegetation communities. The function of these wetland areas is greatly influenced by human activities, primarily through control of surface water and cattle grazing. The PEM1A area south of playas 1 and 2 (see Figure 9) provide a unique opportunity for wetland enhancement. Reduction in grazing and/or permanent exclosures for portions of these areas would improve habitat conditions and attract native species to the area. Such a restoration would enhance an extremely unique system. The likelihood of future INEL facility siting or construction projects other than roads in these areas is small because of the potential for flooding. 

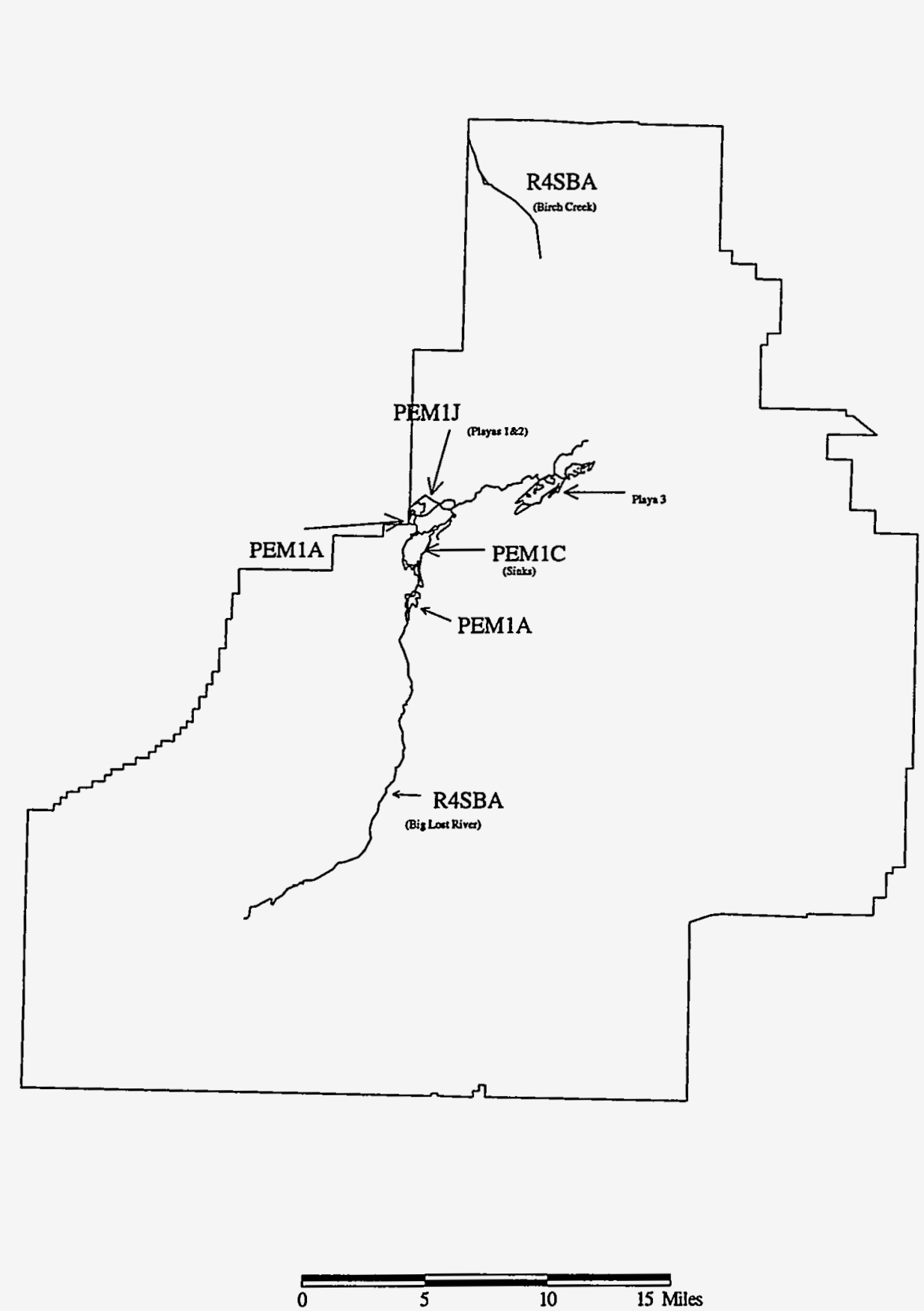

Figure 9. NWI mapped areas of the Big Lost River and Birch Creek drainages on the INEL. 
Approximately seventy percent of the individual NWI wetland sites within INEL boundaries are classified as palustrine areas having unconsolidated shores and intermittent flooding (PUSJ, Table B-1 sites 1-29). Total area encompassed by PUSJ wetlands is just under 20 -ha (50 acres). These wetlands have unique value in that the hydrology of most PUSJ wetlands is not subject to human controls. In addition, the possess unique features such as wide distribution, uncommon vegetative composition, interconnected networks of playas, and high evidence of wildlife use. Examples of these unique characteristics are demonstrated by three wetlands in Antelope Butte and 10 of 15 sites in Little Butte quadrangles (Table B-1 sites 11, 13-20, 24). Extended drought and the season in which this survey was conducted limited vegetative and hydrological assessment of these sites was incomplete. Although no water was present at any PUSJ site, the lack of vegetation and landscape characteristics indicate that water is present during some parts of the year when norimal precipitation is available, no information exists on the frequency or duration of the standing water. No information exists for soil composition of these areas. Isolation, unique vegetation, varied topography, and presence of water at certain times during the season, provide conditons for increased probability for presence of threatened and/or endangered plant and animal species. Oxytheca (Oxytheca dendroidea) has been observed near some wetlands visited during this survey. The pygmy rabbit (Brachylagus idahoensis [Sylvilagus idahoensis]) is an inhabitant of these areas and is "under consideration for threatened or endangered listing, but conclusive data are presently lacking to support the final decision" (Reynolds, 1992). Evidence of wildlife use was observed at all PUSJ sites, and nearly one third of the sites had signs of heavy use. Use patterns are not documented for these sites, however, antelope (Antilocapra americana) appear to frequent nearly every area and several receive concentrated use by elk (Cervus canadensis). Many of these sites also appear to support large communities of burrowing rodents, rabbits, and woodrats (Neotoma cinereus). This concentrated prey source may be speculated to attract carnivores and evidence gathered during the survey indicates that coyotes (Canis latrans) visit these areas. Other predators including bobcats (Lynx rufus), weasles, skunks, foxes, badgers, and raptors also frequent PUSJ sites in search of prey, however their use relative to other areas is unknown. Importance of PUSJ sites to insects, amphibians and reptiles is unknown. Observations or evidence recorded at PUSJ sites during this survey includes elk (Cervus canadensis), antelope (Antilocapra americana), coyote (Canis latrans), bobcat (Lynx rufus), blacktailed jackrabbit (Lepus californicus), cottontail (Sylvilagus nuttallii), pygmy rabbit (Brachylagus idahoensis [Sylvilagus idahoensis]), woodrat (Neotoma cinereus), sage grouse (Centrocercus urophasianus), mule deer (Odocoileus hemionus), and various burrowing rodents. Archaeological 
evidence for these areas was moderate overall, but substantial quantities of material were noted at several individual sites.

Stressors to these areas include sedimentation and altered drainage (e.g., road building), invasion by exotic species, potential disruption to hydrological network through disturbance of an associated playa, and alteration of playa surfaces which may affect infiltration rates and alter periodicity.

Potential problems affecting facility siting in these areas include saturated soils, inappropriate drainage, and standing water that may exist is some areas. Many PUSJ sites are located in upland areas that may be considered for siting because of the unsuitability of locations closer to the Big Lost River.

A number of unclassified and unmapped sites (including the Birch Creek drainage and TRA waste treatment pond) investigated for the survey may meet wetlands criteria, however, were not included by the NWI. These areas are discussed in Section 4.5.

An important factor affecting the delineation of INEL wetlands is their intermittent nature. As a result of temporal variability in precipitation patterns and available snowmelt, INEL wetlands have unique characteristics relative to "classic" wetland habitats. There is an apparent need to address this uniqueness with criteria that address the local characteristics of the INEL ecosystem. Before these criteria can be developed, additional characterization of the ecological significance, temporal, and spatial relationships of these areas should be conducted. These criteria would not necessarily redefine a wetland, but would address the concern to protect unique areas that have ecological significance on the INEL. These areas include wetlands and wetland-like habitats and their associated communities.

The results of this survey represent a first step toward a definitive characterization of INEL wetlands. An overview of wetland habitats that exist on the INEL was produced and general characteristics for each NWI classification were described. Preliminary mapping of INEL wetlands information has been completed using a GIS (ARCINFO) and plans are underway for creating a database to manage information from this and future ecological surveys. 
The information compiled for this survey can be used to locate mapped wetlands (wetland maps, GIS automated map), determine basic characteristics associated with a wetland class (Section 4.1), review survey results, characteristics, and relative importance for a specific wetland (Table B-1, survey field forms, archived $35 \mathrm{~mm}$ slides), and identify additional information needs (Section 5).

The information gathered from this survey can be used for general discussion about the identified wetlands on the INEL as discussed above. However, if a specific location is to be evaluated for potential impacts from INEL activities, a more comprehensive investigation should be initiated. This investigation should include gathering additional information on soil characteristics, geological/geomorphological features, plant community composition, abundance, cover, habitat use, and archaeological and paleontological evidence. This information should be used to assess the importance of the area from a sitewide perspective, i.e. how ecologically important is the area relative to other communities on the INEL and how can potential impacts to the native community be minimized.

The conclusions from this survey are summarized below:

1. There are numerous areas with wetland characteristics distributed throughout the INEL. Most of the INEL wetland areal extent is associated with the Big Lost River system (includes river channel(s), spreading areas, and playas). Significant numbers of small wetlands are also distributed across the INEL (see map). The Birch Creek was not included on the NWI maps, however, the survey sites indicated that important riparian habitat exists along this channel.

2. The areas surveyed range from high ecological importance to no ecological importance (as a wetland). This "relative" ranking scale is based on observations made and/or historical documentation.

3. The surveyed areas would need additional characterization and ecological studies to determine their ecological significance to the INEL ecosystem. The wetlands on the INEL are generally not what one would consider a "classic" wetlands, consequently determining typical wetland ecological significance is difficult. Though these areas appear primarily as playas or dried-up 
stream beds, they may provide important habitat during periods with above average precipitation and snowfall. Though periodic, such situations may play an important role for the resident community and migratory organisms.

4. The NWI wetland mapping completed for the INEL thus far has some errors and inconsistencies, and additional discussions with the FWS regarding verification and reclassification could improve the accuracy of the NWI wetland maps.

5. INEL activities that might impact identified wetlands or areas with wetland characteristics should initially include an assessment of the information generated for this report, and possibly conduct more detailed studies of the areas in question. Soils characteristics would be necessary, at a minimum, to verify wetland criteria for the areas surveyed.

6. The temporal characteristics of the INEL wetlands are such that they are difficult to delineate as wetlands in many cases. New delineation criteria may or may not address these difficulties. In the interim, the intent of preserving wetland habitats should be considered when determining how areas with wetland characteristics should be addressed. 


\section{REFERENCES}

Bennett, C. M. 1990. Streamflow Losses and Ground-Water Level Changes along the Big Lost River at the Idaho National Engineering Laboratory, Idaho. U.S. Geology Survey, Water-Resources Investigations Report 90-4067.

Bright, R. C. and O. K. Davis. 1982. "Quaternary paleoecology of the Idaho National Engineering Laboratory, Snake River Plain, Idaho." The American Midland Naturalist 108 (1):21-33.

Compliance with the National Environmental Policy Act, Part 1021. 1992. In Code of Federal Regulations, Energy, Part 500 to end. Office of the Federal Register National Archives and Records Administration. U.S. Government Printing Offices, Washington, DC.

Cholewa, A. F. and D. M. Henderson. 1984. "A survey and assessment of the rare vascular plants of the Idaho National Engineering Laboratory." Radiological and Environmental Sciences Laboratory. DOE/ID-12100. Idaho Falls, ID. pp. 45.

Cowardin, L. M., V. Carter, F. C. Golet, and E. T. LaRoe. 1979. "Classification of wetlands and deepwater habitats of the United States." U.S. Department of the Interior, Fish and Wildlife Service. FWS/OBS-79/31. pp. 103.

Environmental Laboratory. 1987. Corps of Engineers Wetland Delineation Manual. U.S. Army Engineer Waterways Experiment Station, Vicksburg, MS. Technical Report Y-87-1. 100 pp. plus appendicies.

Federal Interagency Committee for Wetland Delineation. 1989. Federal Manual for Identifying and Delineating Jurisdictional Wetlands. U.S. Army Corps of Engineers, U.S. Environmental Protection Agency, U.S. Fish and Wildlife Service, and U.S.D.A. Soil Conservation Service, Washington, DC Cooperative technical publication. $76 \mathrm{pp}$. plus appendices.

Halford, D. K. and J. B. Millard. 1978. "Vertebrate fauna of a radioactive leaching pond complex in Southeastern Idaho." Great Basis Naturalist $\underline{38(1): 64-70 .}$

Halford, D. K., J. B. Millard and O. D. Markham. 1976. "Waterfowl study of the Test Reactor Area Radioactive Leaching Pond." 1975 Progress Report, Idaho National Engineering Laboratory Site Radioecology-Ecology Programs. IDO-12080. pp. 19.

Howe, F. P. 1986. Masters Thesis, South Dakota State University. An Ecological Study of Mourning Doves in a Cold Desert Ecosystem on the Idaho National Engineering Laboratory.

Jones, K. B. 1986. "Deserts". Chapter 6 In: Cooperider, A. Y., R. J. Boyd, and H. R. Stuart, eds. Inventory and Monitoring of Wildlife Habitat. U. S. Department of the Interior, Bureau of Land Management. Service Center, Denver, CO. 858 pp.

McBride, R., N. R. French, A. H. Dahl, and J. E. Detmer. 1978. Vegetation types and surface soils of the Idaho National Engineering Laboratory Site. IDO-12084. National Technical Information Service, Springfield, VA, 29 pp. 
Miller, S. J. 1993. EG\&G Idaho Inc., Chemical Services. Written communication.

Mueller-Dombois, D. and H. Ellenberg. 1974. "Aims and methods of vegetation ecology." John Wiley and Sons, New York. p. 574.

Olson, G. L. and D. J. Jeppeson. 1993. Soils of the Idaho National Engineering Laboratory. EGG-CEMA-10641.

Overton, C. K. 1977. Masters Thesis, Idaho State University. Description, Distribution, and Density of Big Lost River Salmonid Populations.

Plummer, A. P., S. B. Monsen, and R. Stevens. 1977. Intermountain Range Plant Names and Symbols. U.S. Department of Agriculture, Forest Service. GTR INT-38. pp. 82.

Reed, P. B. Jr. 1988. National List of Plant Species That Occur in Wetlands: Northwest Region (Region 9). U.S. Department of the Interior, Fish and Wildlife Service. Biological Report 88(26.9). pp. 89.

Reynolds, T. D. 1992. Letter to T. L. Perkins, DOE-ID, Subject: "Field evaluation for IWPF and MLLWTF-AM/EP-RESL-92-436," 2 December 1992.

Tiner, R. W. jr. 1989. Clarification of the U.S. Fish and Wildlife Service's Wetland Definition. National Wetlands Newsletter. May-June.

U.S. Environmental Protection Agency. 1991. Proposed Revisions to the Federal Manual for Delineating Wetlands. U.S. Environmental Protection Agency. Washington, DC.

U.S. Fish and Wildlife Service. 1990. Photointerpretation Conventions for the National Wetlands Inventory. U.S. Department of the Interior, Fish and Wildlife Service, St. Petersburg, FL. $43 \mathrm{pp}$. plus appendices.

U.S. Forest Service. 1991. Chapter 2670. "Threatened, Endangered, and Sensitive Plants and Animals." Forest Service Manual 2600, Wildlife, Fish, and Sensitive Plant Habitat Management, Washington, DC.

Wilen, B. 1988. National Wetlands Inventory. Special report (In) Tuesday Letter. National Association of Conservation Districts. Vol 38, No. 9 pages $1-4$. 


\section{APPENDIX A}

\section{WETLAND GIS FIELD DOCUMENTATION FORMS}

A-1 


\section{WETLAND/GIS FIELD DOCUMENTATION FORM}

\section{GENERAL:}

Field Investigator(s) J. Glennon, N. Hampton

Date 12 October 1992

Time of Day_ 0945

Weather Mostly cloudy, 50's

Plot No._ANTBU1_ Veg. Map Classification_Saltbush/

Approximate Size of Site $100 \mathrm{~m}$ diameter - circular outline

GPS File No._ANTBU1 GPS Documentation Form No.

Location (UTM, Lat.Long.)

General Location Description_S. side of T-9 just west of junction of T-9 and T-22

Photographs? ( Y , N ) Roll \#_ 1 _ Frame \#'s $\quad$ 2 through 8

Subject(s) and/or Directions of Photos_Site \#, N,W,S,E, down, edge

Video? ( $\mathrm{Y}, \mathrm{N}$ ) Tape \# Counter \#

General Description of Site_ Typical playa appearance - mud cracks, some scattered lava

pebbles, edge looks like it is flooded periodically - has dead vegetation - some flaking of the

surface of the mud and litter

\section{ARCHAEOLOGY:}

Archaeological Finds? ( $\mathrm{Y}, \mathrm{N}$ ) Description, Location and Density:

1 midsection of a point on the north edge of the playa in the sage border $11 / 4^{\prime \prime}$ long and $1^{\text {" }}$ wide

\section{WILDLIFE:}

Wildlife Observations/Signs of Habitat Use? ( $Y, N$ )

General Description:_Elk scat (heavy) and tracks, grouse scat (heavy), jackrabbit scat, and coyote scat

Sensitive Species or Habitat Present or Nearby? ( $\mathrm{Y}, \mathrm{N}$ )

Description:

\section{WETLAND DETERMINATION:}

Determination Method (Circle): Routine, Intermediate, Comprehensive

Do normal environmental conditions exist at the Plant Community?

Yes, No (If No, explain below)

Has the vegetation, soils, and/or hydrology been significantly disturbed?

Yes , No (if Yes, explain below)

\section{GENERAL FIELD INDICATORS:}

Hydrology

Drainage

Vegetation 


\section{SOILS:}

Soil File No(s).

Soil Sample? ( $\mathrm{Y}, \mathrm{N}$ ) Sample No(s).

Archived? ( $Y, N$ ) Location

Soil Analysis Planned? ( $\mathrm{Y}, \overline{\mathrm{N}}$ )

Slope Flat Aspect

Rock Color: Wet

Soil Color: Wet 10 YR 5/3

Series/Phase

Is the soil on the hydric soils list? $\mathrm{Y}, \mathrm{N}$, Undetermined

Is the soil a Histosol? $\mathrm{Y}, \mathrm{N}$ Histic epipedon present? $\mathrm{Y}, \mathrm{N}$

Is the soil: Mottled? $\mathrm{Y}, \mathrm{N}$

Matrix Color:

Other Hydric Soil Indicators:

Soil Surface_Silt/Clay

Comments:

\section{HYDROLOGY:}

Is the ground surface inundated? $\mathrm{Y}, \mathrm{N}$ Surface water depth:

Is the soil saturated? $\mathrm{Y}, \mathrm{N}$

Depth to free-standing water in pit/soil probe hole:

Mark other field indicators of surface inundation or soil saturation below:

Oxidized root zones

Water marks

Drift lines

Water-stained leaves
Water-borne sediment deposits

Surface scoured areas

Wetland drainage patterns

Morphological plant adaptations

Additional hydrologicindicators:

Comments:_Animal tracks are sunken in the mud showing water was present here earlier in the year - also there are numerous mud cracks.

\section{WETLAND CLASSIFICATION:}

Wetland Criteria Met?:

Hydrology: ( $Y, N$, UNK ) Soils: ( $Y, N$, UNK )

Vegetation: ( $Y, N$, UNK )

$\operatorname{Revisit}(\mathrm{Y}, \mathrm{N})$ :

What Time of Year?

What Type of Year?

PresenFWSClassification PUSJ

Field Determination of Classification

Comments: 
Vegetation Documentation Sheet

Plot No.___ ANTBU1

Date 12 Oct 93

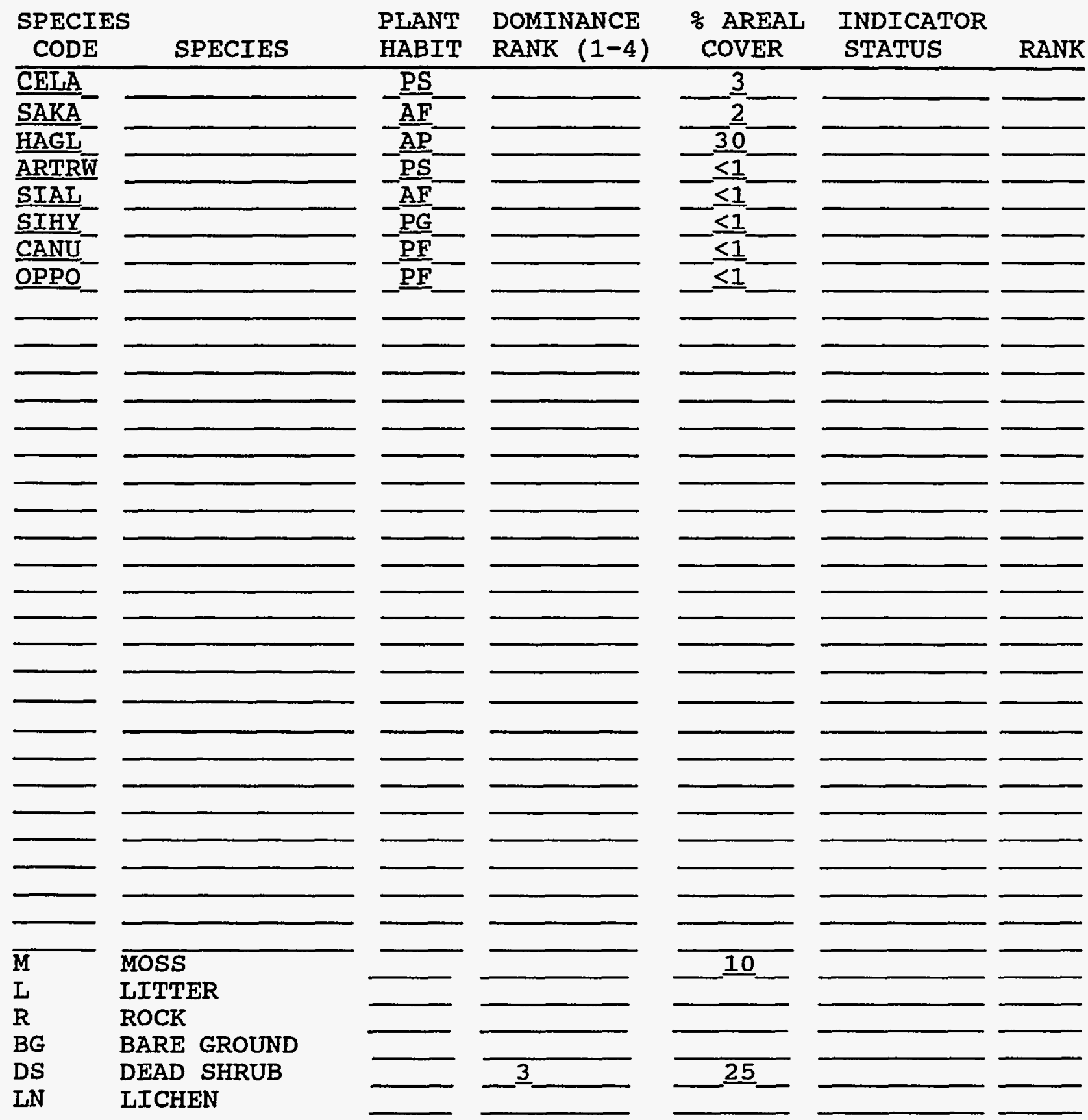

PLANT HABIT:

$A=$ Annual, $B=$ Biennial, $P=$ Perennial $\mathrm{F}=$ Forb, $\mathrm{S}=$ Shrub, $\mathrm{T}=$ Tree, $\mathrm{G}=$ Graminoid
DOMINANCE RANK:

$4=$ Dominant (or co-dominant) $3=$ Common, but not dominant $2=$ Present, not common $1=$ Rare, one to a few
INDICATOR STATUS AND RANK:

Obligate Wetland $\quad=\mathrm{OBL}=1.0$

Facultative Wetland $\quad=$ FACW $=2.0$

Facultative $\quad=$ FAC $=3.0$

Facultative Upland $\quad=$ FACU $=4.0$

Obligate Upland

$=$ UPL $=5.0$

Comments: Playa currently has no vegetation - some dead halogeten winterfat plants occur at the edge of the playa - vegetation surrounding the playa is listed above. 


\section{ARCHAEOLOGY:}

Archaeological Finds? ( $Y, N$ ) Description and Location: If any archaeological objects or structures (rock rings, rock walls) are found, circle $\mathrm{Y}$ and give their description and where they were found relative to GPS location fix, otherwise circle $N$. When found estimate highest density of material (maximum: number of objects/square meter)

\section{WILDLIFE:}

Wildlife Observations/Signs of Habitat Use? ( $Y, N$ )

General Description: If any wildlife, or signs of any (such as tracks, scat, owl pellets, etc.), are observed in the area circle $\mathrm{Y}$ and make a note of it here. Otherwise circle $\mathrm{N}$.

Sensitive Species or Habitat Present or Nearby? ( $Y, N$ )

Description: If any species which are threatened, endangered or sensitive are found or if any possible habitat is available for their use (e.g. crevices/cave for bats, juniper tree among the sagebrush for nesting, specific food resource available) make a note of the species or habitat or resource present and its location.

\section{WETLAND DETERMINATION:}

Onsite Determination Method: Mark the method used in the field check for wetland determination (routine, intermediate or comprehensive) as given in the Federal Manual. (When comprehensive method is necessary vegetation must be checked with line intercept method - see Federal Manual)

Do normal environmental conditions exist at the Plant Community? Yes, No (If No, explain below): If any abnormal conditions (e.g. drought, flood, etc.) exist at the site make a note of them here.

Has the vegetation, soils, and/or hydrology been significantly disturbed? Yes, No (if Yes, explain below): If any signs of disturbance are seen they should be noted and described here.

\section{GENERAL FIELD INDICATORS:}

Hydrology, Soils, Vegetation: Give a general description of any obvious characteristics showing wetland conditions (i.e. signs of past water, drainage patterns, vegetation die-off from inundation, specific obligate wetland species, playa soil and appearance, etc.) These will help later investigators if these characteristics are missing when revisited. 


\section{SOILS:}

Soil File No(s).: Give the file number/name of any soil data or form filled out.

Soil Sample? ( $Y, N$ ) Sample No(s).: If any soil samples are taken circle here and give the sample number(s).

Archived? ( $Y, N$ ) Location: If soil samples are taken, circle and give the location of where they have been archived.

Soil Analysis Planned? $(Y, N)$ : Circle if the collected soil samples are going to be analyzed further or not.

Slope: Give the slope of the study plot (in degrees or per cent).

Aspect: Give the direction the plot is facing in compass degrees (using magnetic readings) or a general compass direction (e.g. NNE, E, SW, etc.).

Soil Surface: Give the texture of the soil surface (e.g. sandy, silt/clay, pebbles, etc.).

Rock Color: Give the wet and dry color of the prevailing rocks on the plot present using the Munsell color chart.

Soil Color: Give the wet and dry color of the soil present on the plot using the Munsell Color Chart.

Series/Phase: Give the proper series/phase name of the soil.

Subgroup: Give the soil subgroup according to USDA, Soil Conservation Service Agriculture Handbook: "Soil Taxonomy."

Is the soil on the hydric soils list? $\mathrm{Y}, \mathrm{N}$, Undetermined: Mark whether the soil on the plot is listed as a hydric soil.

Is the soil a Histosol? $\mathrm{Y}, \mathrm{N}$ : Circle whether the soil is a histosoil or not.

Histic epipedon present? $Y, N$ : Circle if a histic epipedon is present.

Is the soil: $\quad$ Mottled? $\mathrm{Y}, \mathrm{N}$ : Circle the correct answer.

Gleyed? Y, N: Circle the correct answer.

Matrix Color: Give the matrix color of the soil.

Mottle Colors: Give the color(s) of any mottling present.

Other Hydric Soil Indicators: List any other indicators that the soil is hydric.

Comments: Give any final comments on the soil properties here. 


\section{IIDROLOGI:}

Is the ground surface inundated? $Y, N$ Surface water depth: Circle the appropriate response and, if yes, give the water depth.

Is the soil saturated? $Y, N$ : Check with soil pit or soil probe to see if the soil is saturated with water. Check to see if any water can be squeezed or shaken from the soil at the surface.

Depth to free-standing water in pit/soil probe hole: If any free-standing water is present in the soil pit or soil probe hole measure its depth.

Mark other field indicators of surface inundation or soil saturation below: If any of the following indications of the past presence of water are visible then check the appropriate blank:

Oxidized root zones

Water marks

Drift lines

Water-stained leaves
Water-borne sediment deposits

Surface scoured areas

Wetland drainage patterns

Morphological plant adaptations

Additional hydrologic indicators: If any other visible sign of past water is present in the plot or surrounding area then list and describe it here.

Comments: List any other notes or comments about the presence or absence of water or any future check that should be conducted.

\section{WETLAND CLASSIFICATION:}

Wetland Criteria Met?: After conducting the field survey decide whether the definitions for the following categories have been met and circle the proper response. If unknown or further study is necessary then decide what further needs to be done and note it below or in the above sections.

Hydrology: $(Y, N$, UNK), Soils: $(Y, N, U N K)$

Vegetation: $(Y, N, U N K)$

Revisit ( $Y, N$ ): Decide if the study site needs revisiting in order to complete the field determination, circle the correct choice and answer the next questions. This could be for checks in the spring for the presence of water, in the winter for snowpack data, for the presence of ephemeral vegetation, etc. The area could be flooded annually or only with a significant snowpack in the winter. All possibilities must be examined if in doubt.

What Time of lear? If a certain time of the year will dictate when to visited the site, note it here. This could be spring, winter, after runoff, throughout the growing season, etc.

What Type of Year? Give the type of year necessary for a revisit. This could be a typical year, a wet year, a drought year, several wet years in succession, etc. 
Present FWS Classification: Give the present classification by the U.S. Fish and Wildife Service for this site.

Field Determination of Classification: Classify this site as to whether it is a wetland or not, or any of the difficult to classify areas by using the "Federal Manual for Identifying and Delineating Jurisdictional Wetlands" and give the classification as determined by the FWS Publication "Classification of Wetlands and Deepwater Habitats of the United States."

Comments: Give any final notes and comments on the determination and classification of the study area.

\section{VEGETATION DOCUMENTATION SHEET}

Species Code: Give the 4 - 5 digit alphanumeric code for Intermountain Plant Names as used by the Forest Service.

(e.g. ARTRW = Artemisia tridentata, subspecies wyomingensis)

Species: Write out the plant species name.

Plant Habit: Using the code listed at the bottom of the form give the normal form of this plant. (e.g. $\mathrm{AF}=$ Annual Forb)

Dominance Rank: Using the number ranking at the bottom of the form list the abundance of each species present.

\% Areal Cover: Give an approximation of the cover for each species present.

Indicator Status: Using the "National List of Plant Species That Occur in Wetlands" for this region place the code listed at the bottom of the form in this column.

Rank: From the status column give the numerical code in this column as shown at the bottom of the field form.

Comments: Use this space for any comments about the vegetation or absence of expected vegetation here. This could be because of the time of year, dry conditions, etc. 


\section{APPENDIX B}

INEL WETLANDS SURVEY DATA

B-1 


\begin{tabular}{|c|c|c|c|c|c|c|c|c|c|c|}
\hline 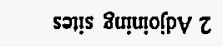 & I & 2uoN & $\mathrm{H}$ & 28pg / pung & บорРоренН /28:S & DUON & us $\times$ u. ug & 6MNกGLIT & & $6 I$ \\
\hline & 1 & W & H & ung $/ 28 \mathrm{pg} / 28 \mathrm{BS}$ & 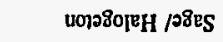 & นกวว8ิอГยน & usl $\times$ uss & 8MNกGLIT & & 81 \\
\hline 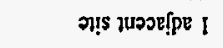 & I & $7 / \mathrm{d}$ & $\mathrm{H}$ & umg $\Omega$ भu $\Omega$ & 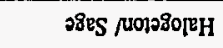 & ouON & wst $x$ wsL & LMNกELIT & & ८I \\
\hline SMNกGLIT OS| ग्S & I & SUON & H & $28 \mathrm{pg} / 28 \mathrm{eS}$ & 4snuqossoh p8Rs & פUON & $u_{0} 0 z \times u_{0 z}$ & 9MNกGLIT & & 91 \\
\hline 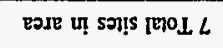 & I & $T / Y$ & H & 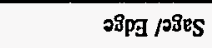 & 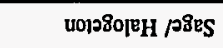 & 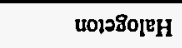 & ws $x$ wst & SMNกGLIT & & SI \\
\hline ग!เ วนวכย!pe I & I & गuoN & H & 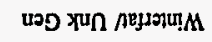 & 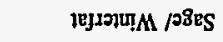 & 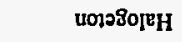 & $w_{01} x$ wos & †MNกg.LIT & & $\nabla I$ \\
\hline \multirow[t]{4}{*}{ 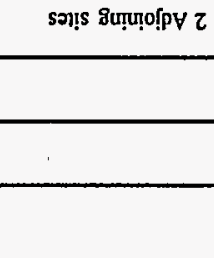 } & I & 200N & $\mathrm{H}$ & 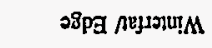 & 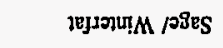 & गUON & $u_{0} \varepsilon \times u_{00 z}$ & EMNกษนT & & દI \\
\hline & $\varepsilon$ & $T / \mathrm{A}$ & $T$ & 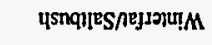 & 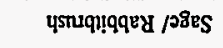 & SuON & $u_{0} s \times u_{00 z}$ & ZMNกタLIT & & 21 \\
\hline & I & 200N & H & पsnqयाएS & 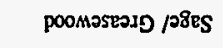 & PUON & $u_{001} \times u_{002}$ & IMNกELIT & & II \\
\hline & $\tau$ & SUON & W & Ssto /ung & 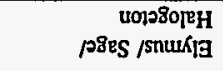 & บัวว8입 & usI $x$ wo & 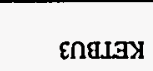 & & 01 \\
\hline \multirow[t]{4}{*}{$8_{2} \Lambda$ onb!u } & 1 & ouoN & $\mathrm{H}$ & 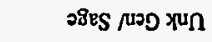 & SnuwSI] & snuKila/tgostes & woS $\times$ wšI & ZกษدรX & & 6 \\
\hline & $\varepsilon$ & T/A & $\mathrm{I}$ & 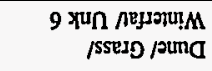 & ssexp pies & иоэอ8ิоген & $u_{0 S} \times u_{0 L}$ & 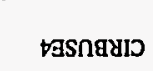 & & 8 \\
\hline & $z$ & H/A & w & 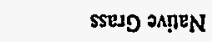 & snur/G $/ 28 \mathrm{es}$ & शUoN & us $x$ wot & દฐSกяบ1ว & & $L$ \\
\hline & $\varepsilon$ & गHON & I & eKe!d / $/ 28 \mathrm{pg} / 28 \mathrm{eS}$ & snuuß但 p8̊s mon & PUON & woe $\times$ usz & İSกяมIว & & 9 \\
\hline \multirow[t]{2}{*}{ 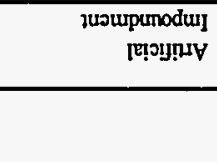 } & $\varepsilon$ & W/d & $T$ & 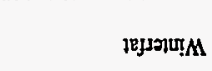 & $28 \mathrm{es}$ & ysnqu|es & $u_{0} 0 t \times u_{08}$ & ILIJWLY & & $s$ \\
\hline & $\tau$ & W/d & $\boldsymbol{w}$ & นง8 xu & $\begin{array}{r}\text { sosseso } \\
\text { Isqnurs pead reposes }\end{array}$ & elosjes & $\mathrm{w}, 09 \times \mathrm{ur}_{002}$ & tกGINV & & $t$ \\
\hline 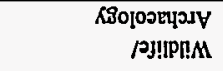 & 1 & H/d & $\mathbf{H}$ & $28 \mathrm{ES}$ & จ8ES / & 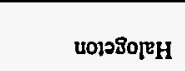 & $w_{0} \mathrm{~S} \times \mathrm{w}_{00 \mathrm{z}}$ & EกGINY & & $\varepsilon$ \\
\hline \multirow[t]{2}{*}{ 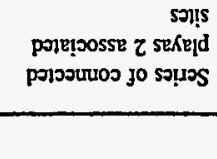 } & 1 & $7 / \mathbf{I}$ & $\mathbf{H}$ & $\begin{array}{r}\text { गSpg /uss } \\
\text { গun } R \text { গun /ung }\end{array}$ & 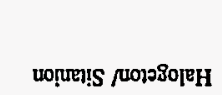 & บ01э8입 H & uros $_{0} \times$ urosI & ZחGINV & & $\tau$ \\
\hline & I & T & $\mathbf{H}$ & 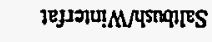 & 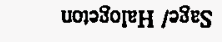 & DUON & $u_{000 I} \times u_{000 I}$ & Inginy & Isnd & ! \\
\hline SINGINWOO & jYNVR & XO070TVHО\&V & \$IIATM & 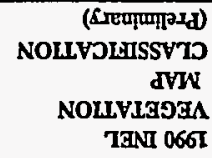 & $\begin{array}{r}\text { Varq } \\
\text { NOLIVIJ9IA }\end{array}$ & $\begin{array}{r}\text { GuIs } \\
\text { NOILVIG9झג }\end{array}$ & VA8\% & .aWVN GIIS & SSVTD & \# G.IS \\
\hline
\end{tabular}


Table B-1. (Continued)

\begin{tabular}{|c|c|c|c|c|c|c|c|c|c|c|}
\hline SITE \# & CLASS & SITE NAME" & AREA & $\begin{array}{l}\text { VEGETATION } \\
\text { SITE }\end{array}$ & $\begin{array}{l}\text { VEGETATION } \\
\text { AREA }\end{array}$ & $\begin{array}{l}1990 \text { INEL } \\
\text { VEGETATION } \\
\text { MAP } \\
\text { CLASSIFICATION } \\
\text { (Preliminary) }\end{array}$ & WILDLIFE & ARCHAEOLOGY' & RANK $^{c}$ & COMMENTS \\
\hline 20 & $\begin{array}{l}\text { PUSI } \\
\text { (cont) }\end{array}$ & LITBUNWA & $50 \mathrm{~m} \times 30 \mathrm{~m}$ & None & Sage/ Halogeton & Winterfat/ Edge/ Burm & $\mathbf{H}$ & None & 1 & I Adjacent site \\
\hline 21 & & LITBUNWB & $15 \mathrm{~m} \times 10 \mathrm{~m}$ & Sage/Grass & Sage/Grass & Sage & L & L & 3 & Disturbed borrow pit \\
\hline 22 & & LITBUNWC & $40 \mathrm{~m} \times 20 \mathrm{~m}$ & Halogeton & Sage/ Winterfat & Unk $2 /$ Edge & $\mathbf{H}$ & None & 2 & \\
\hline 23 & & LTTBUNWD & $10 \mathrm{~m} \times 10 \mathrm{~m}$ & Elymus & Elymus & $\begin{array}{l}\text { Native grass/Crested } \\
\text { wheat }\end{array}$ & L & None & 3 & \\
\hline 24 & & LITBUNWE & $15 \mathrm{~m} \times 10 \mathrm{~m}$ & Elymus & Elymus/ Grass & Native grass & $\mathbf{H}$ & None & 1 & Large basin \\
\hline 25 & & LITBUNWF & $150 \mathrm{~m} \times 100 \mathrm{~m}$ & Elymus & Sage & Edge/ Crestedwheat & $\mathbf{L}$ & None & 2 & \\
\hline 26 & & LITBUSW1 & $20 \mathrm{~m} \times 15 \mathrm{~m}$ & Halogeton & Sage/ Grass & Sage & L & None & 3 & \\
\hline 27 & & LITBUSW3 & $50 \mathrm{~m} \times 30 \mathrm{~m}$ & None & Sage & Sage & M & F/M & 2 & \\
\hline 28 & & LITBUSW5 & $40 \mathrm{~m} \times 20 \mathrm{~m}$ & Halogeton & Halogeton/Sage & Native Grass/ Edge & $\mathbf{L}$ & None & 3 & \\
\hline 29 & & LITBUSW6 & $40 \mathrm{~m} \times 15 \mathrm{~m}$ & Halogeton & Sage/ Rabbitbrush & Edge & L & None & 3 & \\
\hline 30 & PABAHX & CIRBUTAN & $30 \mathrm{~m} \times 15 \mathrm{~m}$ & Dock/ Thistle & Sage & Unk 2 & $\mathbf{L}$ & None & 3 & Waste pond \\
\hline 31 & PEMIA & BIGLOST2 & $500 \mathrm{~m} \times 200 \mathrm{~m}$ & Grass/Saisola & Grass/ Sage & $\begin{array}{l}\text { Native Grass/ Crested } \\
\text { wheal Edge }\end{array}$ & $\mathbf{M}$ & None & 1 & $\begin{array}{l}\text { Sinks- Heavily } \\
\text { Disturbed }\end{array}$ \\
\hline 32 & PEMIC & BIGLOST4 & $1000 \mathrm{~m} \times 1500 \mathrm{~m}$ & Grass & Grass & Wetland & $\mathbf{L}$ & None & 1 & Visit in wet years \\
\hline 33 & & CIRBUNWA & $3 \mathrm{~m}$ wide $\mathrm{x} \operatorname{lm}$ deep & Bulrush & Sage & Edge & $\mathbf{M}$ & None & 2 & Outflow channel \\
\hline 34 & PEMIJ & BIGLOSTI & $3 / 4$ mile $\times 1 / 2$ mile & Weedy annuals & Sage & $\begin{array}{l}\text { Unk 6/ Unk Gen/ } \\
\text { Playa }\end{array}$ & $\mathbf{M}$ & $\mathrm{F} / \mathrm{H}$ & 1 & Sinks- Visit when wet \\
\hline 35 & & BIGLOST5 & $200 \mathrm{~m} \times 300 \mathrm{~m}$ & Grass & Sage & Wetland/Grass & $\mathrm{L}$ & None & 1 & Visit in Wet years \\
\hline 36 & PEMJ & BSBU3 & $40 \mathrm{~m} \times 30 \mathrm{~m}$ & Elymus/ Grass & Sage & Crested Wheat/grass & $L$ & None & 3 & \\
\hline 37 & & BSBU6 & $30 \mathrm{~m} \times 20 \mathrm{~m}$ & Lupine/ Grass & Sage & Native grass/ Edge & M & $\begin{array}{l}\text { F/H } \\
\mathrm{A} / \mathrm{M}\end{array}$ & 3 & Heavily Disturbed \\
\hline 38 & PUSC & CIRBUSW3 & $80 \mathrm{~m} \times 60 \mathrm{~m}$ & Crested wheat & Sage & $\begin{array}{l}\text { Unk gen/ } \\
\text { Unk } 2\end{array}$ & $\mathbf{L}$ & None & 3 & Seeding in Borrow pit \\
\hline
\end{tabular}


Table B-1. (Continued)

\begin{tabular}{|c|c|c|c|c|c|c|c|c|c|c|}
\hline SITE \# & CLASS & SITE NAME" & AREA & $\begin{array}{l}\text { VEGETATION } \\
\text { SITE }\end{array}$ & $\begin{array}{l}\text { VEGETATION } \\
\text { AREA }\end{array}$ & $\begin{array}{l}1990 \text { INEL } \\
\text { VEGETATION } \\
\text { MAP } \\
\text { CLASSIFICATION } \\
\text { (Preliminary) }\end{array}$ & WIDLIFE & ARCHAEOLOGY & RANK $^{\mathrm{c}}$ & COMMENTS \\
\hline 39 & PUSCrx & CIRBUSE7 & $15 \mathrm{~m} \times 20 \mathrm{~m}$ & Rabbibrush & Sage & Edge & L & None & 3 & Excavaled \\
\hline 40 & & CIRBUSE8 & $20 \mathrm{~m} \times 50 \mathrm{~m}$ & $\begin{array}{l}\text { Crested whear } \\
\text { Willow }\end{array}$ & Sage & Facility & L & None & 3 & $\begin{array}{l}\text { Old waste area } \\
\text { Rad contaminated }\end{array}$ \\
\hline 41 & PUSC $x$ & CIRBUSE6 & $20 \mathrm{~m} \times 20 \mathrm{~m}$ & Weedy annuals & Sage & Unk gen & L & None & 3 & Lined waste pond \\
\hline 42 & POWHx & CIRBUNWC & $200 \mathrm{~m} \times 100 \mathrm{~m}$ & Weedy annuals & Sage & Edge/ Unk 6 & L & None & 3 & $\begin{array}{l}\text { Waste pond - } 1 \\
\text { adjacent site }\end{array}$ \\
\hline 43 & & CIRBUNWD & $15 \mathrm{~m} \times 15 \mathrm{~m}$ & Weedy annuals & Sage & Sage- grass & L & None & 4 & $\begin{array}{l}\text { Cement-covered } \\
\text { waste pond }\end{array}$ \\
\hline 44 & & CIRBUNWE & $150 \mathrm{~m} \times 100 \mathrm{~m}$ & Weedy annuals & Sage & Unk gen & L & None & 3 & See CIRBUNWC \\
\hline 45 & & CIRBUSEA & $30 \mathrm{~m} \times 30 \mathrm{~m}$ & Weedy anmuals & Sage & Unk 2 & L & None & 4 & Rubble pit \\
\hline 46 & & CIRBUSW1 & $5 \mathrm{~m} \times 40 \mathrm{~m}$ & None & Sage & Juniper- sage/ facility & $\mathbf{L}$ & None & 4 & Manganese pile \\
\hline 47 & & CIRBUSW2 & $10 \mathrm{~m} \times 10 \mathrm{~m}$ & Sage & Sage & Sage- grass & L & None & 4 & Firing range \\
\hline 48 & & CIRBUTAN & $120 \mathrm{~m} \times 50 \mathrm{~m}$ & Dock/ Thistle & Sage & Unk 2 & $L$ & None & 3 & Waste pond \\
\hline 49 & & CIRBUSW6 & $15 \mathrm{~m} \times 20 \mathrm{~m}$ & None & Sage & Facility & L & None & 3 & $\begin{array}{l}\text { Waste pond/ Gravel } \\
\text { pit }\end{array}$ \\
\hline 50 & & LITBUSW9 & $150 \times 100 \mathrm{~m}$ & Cattail/ Bulrush & Sage & Edge/ Unk 2 & M & None & 2 & Industrial waste pond \\
\hline 51 & & LITBUSWA & $150 \times 100 \mathrm{~m}$ & Weedy annuals & Sage & Unk gen/ Unk 2 & L & None & 3 & Waste pond \\
\hline 52 & & LITBUSWB & $40 \mathrm{~m} \times 40 \mathrm{~m}$ & Weody annuals & Sage & Dune & L & None & 3 & Waste pond \\
\hline 53 & L2USI & BSBU1 & 1 mile $\times 1 / 2$ mile & Grass/ Weeds & Sage & Unk 6 & $\mathrm{~L}$ & None & 2 & Spreading area \\
\hline 54 & & BSBU4 & $800 \mathrm{~m} \times 200 \mathrm{~m}$ & Grass/Weeds & Sage & Dune & L & None & 2 & Spreading area \\
\hline 55 & & BIGLOST8 & $300 \mathrm{~m} \times 150 \mathrm{~m}$ & Milkvetch & Sage & Salbush/ Winterfat & L & $\begin{array}{l}F / H \\
A / L \\
\end{array}$ & 2 & Revisit in wet years \\
\hline 56 & & BIGLOSTY & $3 / 4$ mile $\times 1 / 2$ mile & Grass/ Weeds & Sage & Salbush/ Winterfat & M & F/L & 2 & Revisit in wet years \\
\hline 57 & R2OWHx & CIRBUNWB & $3 \mathrm{~m}$ wide $\times 2 \mathrm{~m}$ decp & Catail/ Bulrush & Sage & Sage/ Edge & L & None & 2 & Outflow channel \\
\hline
\end{tabular}


Table B-1. (Continued)

\begin{tabular}{|c|c|c|c|c|c|c|c|c|c|c|}
\hline SITE \# & CLASS & STTE NAME" & AREA & $\begin{array}{l}\text { VEGETATION } \\
\text { SITE }\end{array}$ & $\begin{array}{l}\text { VEGETATION } \\
\text { AREA }\end{array}$ & $\begin{array}{l}1990 \text { INEL } \\
\text { VEGETATION } \\
\text { MAP } \\
\text { CLASSIITAATION } \\
\text { (Prellminary) }\end{array}$ & WILDLIFE & ARCHAEOLOGY & RANK $^{\mathfrak{c}}$ & COMMENTS \\
\hline 58 & R4SBA & CIRBUNW7 & $15 \mathrm{~m}$ wide $\times 2 \mathrm{~m}$ deep & Sparse & Willow/ Rose & Sage/ Edge & L & None & 2 & $\begin{array}{l}\text { River- visit in wet } \\
\text { year }\end{array}$ \\
\hline 59 & R4SBC & BIGLOST3 & $8 \mathrm{~m}$ wide $\mathrm{x} 1 \mathrm{~m}$ deep & Weedy annuals & Sage & Wetland & $\mathrm{L}$ & None & 2 & Visit in wet year \\
\hline 60 & R4SBJ & BIGLOST6 & Im wide $x \operatorname{lm}$ deep & Weedy annuals & $\begin{array}{l}\text { Grass/ Weedy } \\
\text { annuals }\end{array}$ & Saltbush/ Winterfat & L & None & 2 & Visit in wet year \\
\hline 61 & R4SBJX & BSBU2 & $\begin{array}{l}15 \mathrm{~m} \text { wide } \times 800 \mathrm{~m} \text { long } \\
\times 3 \mathrm{~m} \text { deep }\end{array}$ & Annual weeds & Sage & Bare/ Unk Gen & $\mathbf{L}$ & None & 3 & Visit in wet year \\
\hline 62 & & BSBUS & $\begin{array}{l}5 \mathrm{~m} \text { wide } \times 250 \mathrm{~m} \text { long } \\
\times 2 \mathrm{~m} \text { deep }\end{array}$ & Annual weeds & Sage & Dune/ Edge & L & None & 3 & Visit in wet year \\
\hline 63 & UNMAP & ARCHILI & $150 \times 100 \mathrm{~m}$ & Elymus & Sage & $\begin{array}{l}\text { Native grass/Crested } \\
\text { wheat }\end{array}$ & $M$ & $\begin{array}{l}\mathrm{F} / \mathrm{H} \\
\mathrm{A} / \mathrm{M}\end{array}$ & 1 & Visit in wet year \\
\hline 64 & & ARCHIL2 & $50 \mathrm{~m} \times 30 \mathrm{~m}$ & Elymus & Sage & $\begin{array}{l}\text { Native grass/Crested } \\
\text { wheat }\end{array}$ & L & $\mathrm{F} / \mathrm{L}$ & 2 & \\
\hline 65 & & ARCHIL3 & $75 \mathrm{~m} \times 75 \mathrm{~m}$ & Elymus & Sage & Native grass & $\mathbf{M}$ & $\mathrm{F} / \mathrm{L}$ & 2 & \\
\hline 66 & & ARCHILA & $50 \mathrm{~m} \times 30 \mathrm{~m}$ & Elymus & Sage & $\begin{array}{l}\text { Native grass/ Crested } \\
\text { wheat }\end{array}$ & L & $F / L$ & 3 & \\
\hline 67 & & ARCHILS & $15 \mathrm{mx} 20 \mathrm{~m}$ & None & Sage & Sage & L & $F / L$ & 3 & \\
\hline 68 & & ARCHIL6 & $15 \mathrm{~m} \times 10 \mathrm{~m}$ & None & Sage & Sage & $L$ & $\mathbf{F} / \mathbf{L}^{\prime}$ & 3 & \\
\hline 69 & & ARCHIL7 & $5 \mathrm{~m}$ wide $\times 2 \mathrm{~m}$ deep & Annual Weeds & Cottonwood & Edge/ Sage & $\mathbf{L}$ & None & 3 & Visit in wet year \\
\hline 70 & & ARCHIL8 & $5 \mathrm{~m}$ wide $\times 2 \mathrm{~m}$ deep & Annual weeds & Sage & Sage/ Native grass & $\mathbf{L}$ & None & 3 & Visit in wet year \\
\hline 71 & & BUTCITI & $15 \mathrm{~m}$ wide $\mathrm{x} 4 \mathrm{~m}$ deep & Sage/ Weeds & Chokecherry & Edge/ Unk Gen & $\mathbf{L}$ & None & 2 & $\begin{array}{l}\text { River- Visit in wet } \\
\text { year }\end{array}$ \\
\hline 72 & & BUTCIT2 & $15 \mathrm{~m}$ wide $\times 4 \mathrm{~m}$ deep & Sage/ Weeds & Rose & Edge/ Unk Gen & $\mathrm{L}$ & None & 2 & $\begin{array}{l}\text { River- Visit in wet } \\
\text { year }\end{array}$ \\
\hline 73 & & BUTCIT3 & $15 \mathrm{~m}$ wide $\times 4 \mathrm{~m}$ deep & Sage/ Weeds & Currant & Edge/ Unk Gen & L & None & 2 & $\begin{array}{l}\text { River- Visit in wet } \\
\text { year }\end{array}$ \\
\hline 74 & & BUTCIT4 & $15 \mathrm{~m}$ wide $\mathrm{x} 4 \mathrm{~m}$ deep & Sage/ Weeds & Sage & Edge/ Unk Gen & $\mathbf{L}$ & None & 2 & $\begin{array}{l}\text { River- Visit in wet } \\
\text { year }\end{array}$ \\
\hline
\end{tabular}


Table B-1. (Continued)

\begin{tabular}{|c|c|c|c|c|c|c|c|c|c|c|}
\hline STIE \# & CLASS & SITE NAME & AREA & $\begin{array}{l}\text { VEGETATION } \\
\text { SITE }\end{array}$ & $\begin{array}{l}\text { VEGETATION } \\
\text { AREA }\end{array}$ & $\begin{array}{l}1990 \text { INEL } \\
\text { VEGETATION } \\
\text { MAP } \\
\text { CLASSIFTCATION } \\
\text { (Preliminary) }\end{array}$ & WILDLIFE & ARCHAEOLOGY & RANK $^{\mathbf{c}}$ & COMMENTS \\
\hline 75 & & HOWPKI & $20 \mathrm{~m} \times 15 \mathrm{~m}$ & Elymus & Sage & Sage- Grass & L & $\mathrm{A} / \mathrm{L}$ & 3 & \\
\hline 76 & & HOWPK2 & $50 \mathrm{~m} \times 75 \mathrm{~m}$ & Elymus & Sage & Sage/ Sage- grass & L & $\mathrm{F} / \mathrm{L}$ & 3 & \\
\hline 77 & UNC & ANTBUS & 1 mile $x 1 / 2$ mile & Salsola & Sage & Playa & M & $\mathrm{F} / \mathrm{L}$ & 3 & \\
\hline 78 & & BIGLOST7 & $200 \mathrm{~m} \times 80 \mathrm{~m}$ & None & Saltbush & Dune/ Edge & $\mathbf{L}$ & None & 3 & \\
\hline 79 & & CIRBUI & $300 \mathrm{~m} \times 600 \mathrm{~m}$ & None & $\begin{array}{l}\text { Rabbitbrush/ Sagel } \\
\text { Winterfat }\end{array}$ & Unk 2/ Bum & $\mathbf{L}$ & None & 3 & \\
\hline 80 & & CIRBUNE! & $300 \mathrm{~m} \times 150 \mathrm{~m}$ & None & Sage/ Grass & Saltbush/ Winterfat & $\mathbf{L}$ & None & 3 & \\
\hline 81 & & CIRBUNE2 & $170 \mathrm{~m} \times 60 \mathrm{~m}$ & None & Sage/ Halogeton & Saltbush/ Winterfat & $M$ & $\mathrm{~F} / \mathrm{M}$ & 2 & \\
\hline 82 & & CIRBUNE3 & $25 \mathrm{~m} \times 30 \mathrm{~m}$ & None & Rabbitbrush & Sage & M & $\begin{array}{l}\mathrm{F} / \mathrm{M} \\
\mathrm{A} / \mathrm{L}\end{array}$ & 2 & \\
\hline 83 & & CIRBUNE4 & $15 \mathrm{~m} \times 60 \mathrm{~m}$ & None & Sage/ Horsebrush & Edge/ Unk 2 & $\mathbf{L}$ & $\mathrm{F} / \mathrm{M}$ & 3 & \\
\hline 84 & & CIRBUNES & $80 \mathrm{~m} \times 40 \mathrm{~m}$ & Salsola/ Sage & Sage & Edge & $\mathbf{L}$ & None & 3 & \\
\hline 85 & & CIRBUNWI & $40 \mathrm{~m} \times 300 \mathrm{~m}$ & None & Elymus/ Greasewood & Bare/ Edge/ Unk gen & $M$ & $\mathrm{~F} / \mathrm{M}$ & 2 & \\
\hline 86 & & CIRBUNW2 & $300 \mathrm{~m} \times 30 \mathrm{~m}$ & None & Sage & Sallbush/ Winterfat & L & None & 3 & \\
\hline 87 & & CIRBUNW3 & $100 \mathrm{~m} \times 100 \mathrm{~m}$ & Saltbush & Sage/ Elymus & Saltbush// Winterfat & L & $\begin{array}{l}\mathrm{A} / \mathrm{M} \\
\mathrm{FM} \\
\end{array}$ & 3 & \\
\hline 88 & & CIRBUNW4 & $100 \mathrm{~m} \times 15 \mathrm{~m}$ & None & Sage/ Saltbush & Saltbush/ Edge & $\mathbf{L}$ & None & 3 & \\
\hline 89 & & CIRBUNWS & $150 \mathrm{~m} \times 75 \mathrm{~m}$ & None & Sage/ Grass & Winterfat/ Edge & L & $\mathrm{A} / \mathrm{L}$ & 3 & \\
\hline 90 & & CIRBUSE2 & $15 \mathrm{~m} \times 10 \mathrm{~m}$ & None & Low sage & Dune/ Grass & $\mathbf{L}$ & None & 3 & \\
\hline 91 & & CIRBUSES & $40 \mathrm{~m} \times 30 \mathrm{~m}$ & Halogeton & Sage/ Grass & $\begin{array}{l}\text { Native grass/ Burn/ } \\
\text { Unk } 2\end{array}$ & $M$ & $\mathrm{~F} / \mathrm{M}$ & 3 & Man-made Catchment \\
\hline 92 & & CIRBUSW4 & $100 \mathrm{~m} \times 30 \mathrm{~m}$ & $\begin{array}{l}\text { Sedge/ Rush' } \\
\text { Weeds }\end{array}$ & Sage & $\begin{array}{l}\text { Native grass/ Crested } \\
\text { wheat }\end{array}$ & $\mathbf{M}$ & None & 2 & TRA Outflow \\
\hline 93 & & CIRBusWs & $150 \mathrm{~m} \times 200 \mathrm{~m}$ & Dock & Sage & Bare ground/ Unk 2 & L & None & 3 & CPP Waste pond \\
\hline
\end{tabular}


Table B-1. (Continued)

\begin{tabular}{|c|c|c|c|c|c|c|c|c|c|c|}
\hline SITE \# & CLASS & SITE NAME• & AREA & $\begin{array}{l}\text { VEGETATION } \\
\text { STTE }\end{array}$ & $\begin{array}{l}\text { VEGETATION } \\
\text { AREA }\end{array}$ & $\begin{array}{l}1990 \text { INEL } \\
\text { VEGETATION } \\
\text { MAP } \\
\text { CLASSIFICATION } \\
\text { (Preliminary) }\end{array}$ & WILDLIFE & ARCHAEOLOGY" & RANK $^{c}$ & COMMENTS \\
\hline 94 & & KETBUI & $250 \mathrm{~m} \times 75 \mathrm{~m}$ & Saltbush/Grass & Sage & Sage/ Native grass & H & None & 2 & Elymus stand nearby \\
\hline 95 & & LITBUNE1 & 1 mile $x 1 / 2$ mile & Elymus & Elymus/ Sage & $\begin{array}{l}\text { Grass/ } \\
\text { Crested wheat }\end{array}$ & H & $A / L$ & 1 & Revisit in wet year \\
\hline 96 & & LITBUNE2 & $60 \mathrm{~m} \times 50 \mathrm{~m}$ & Halogeton & Elymus/ Sage & Crested wheat/ Unk 2 & H & $\mathrm{F} / \mathrm{H}$ & 2 & \\
\hline 97 & & LITBUNE3 & $15 \mathrm{~m} \times 10 \mathrm{~m}$ & Halogeton & Sage/ Grass & Sage & $\mathbf{L}$ & None & 3 & \\
\hline 98 & & LITBUSW2 & $10 \mathrm{~m} \times 10 \mathrm{~m}$ & None & Grass/Sage & Sage & M & F/L & 3 & \\
\hline 99 & & LITBUSW4 & $100 \mathrm{~m} \times 40 \mathrm{~m}$ & Halogeton & Elymus/Grass/Sage & Sage & $\mathrm{L}$ & $\mathrm{F} / \mathrm{L}$ & 3 & \\
\hline 100 & & LITBUSW7 & $1 / 2$ mile $\times 1 / 2$ mile & Elymus & Elymus/ Sage & & L & $\mathrm{F} / \mathrm{L}$ & 3 & \\
\hline 101 & & LITBUSW8 & $40 \mathrm{~m} \times 20 \mathrm{~m}$ & Halogeton & Sage/ Grass & & $\mathbf{M}$ & None & 3 & \\
\hline 102 & & RICHBUT1 & $20 \mathrm{~m}$ wide $\times 2 \mathrm{~m}$ deep & $\begin{array}{l}\text { Elymus/ Birch/ } \\
\text { Willow/ Rose }\end{array}$ & Sage & Edge & L & None & 2 & Visit in wet year \\
\hline 103 & & RICHBUT2 & $5 \mathrm{~m}$ wide $\mathrm{x} 1 \mathrm{~m}$ deep & $\begin{array}{l}\text { Cottonwood } \\
\text { Elymus/ } \\
\text { Currant }\end{array}$ & Sage & Edge & $\mathbf{L}$ & None & 2 & Visit in wet year \\
\hline 104 & & RICHBUT3 & $2 \mathrm{~m}$ wide $\mathrm{x} 1 \mathrm{~m}$ deep & Elymus/Rose & Sage & Sage & $\mathrm{L}$ & None & 2 & Visit in wet year \\
\hline 105 & & RICHBUT4 & $2 \mathrm{~m}$ wide $\times \operatorname{Im}$ deep & $\begin{array}{l}\text { Sage/ Elymus/ } \\
\text { Rose }\end{array}$ & Sage & Edge & M & None & 2 & Visit in wet year \\
\hline
\end{tabular}

- Each site was assigned an identifier comprised of the abbreviated quadrangle in which they were located and an ascending number representing the order in which the sites within the quadrangle were visited. Identifiers were limited to 8 characters. For numbering past 9, alpha characters were used, for example, CIRBUNW3 represents the third site visited in the Circular Butte 3 NW quadrangle and LITBUNWA the tenth site visited in the Little Butte NW quadrangle.

b - high; M - moderate; L - low; F - flakes; A - artifacts

c 1 - wetland appears to have high potential ecological importance

2 - wetland appears to have moderate potential ecological importance

3 - wetland appears to have lower potential ecological importance

4 - no apparent wetlands characteristics

See Section 4 for a discussion of ranking procedure 


\section{APPENDIX C}

INEL WETLAND SURVEY

PLANT SPECIES LIST

C-1 
Table C-1. INEL Wetland Survey - Plant Species List

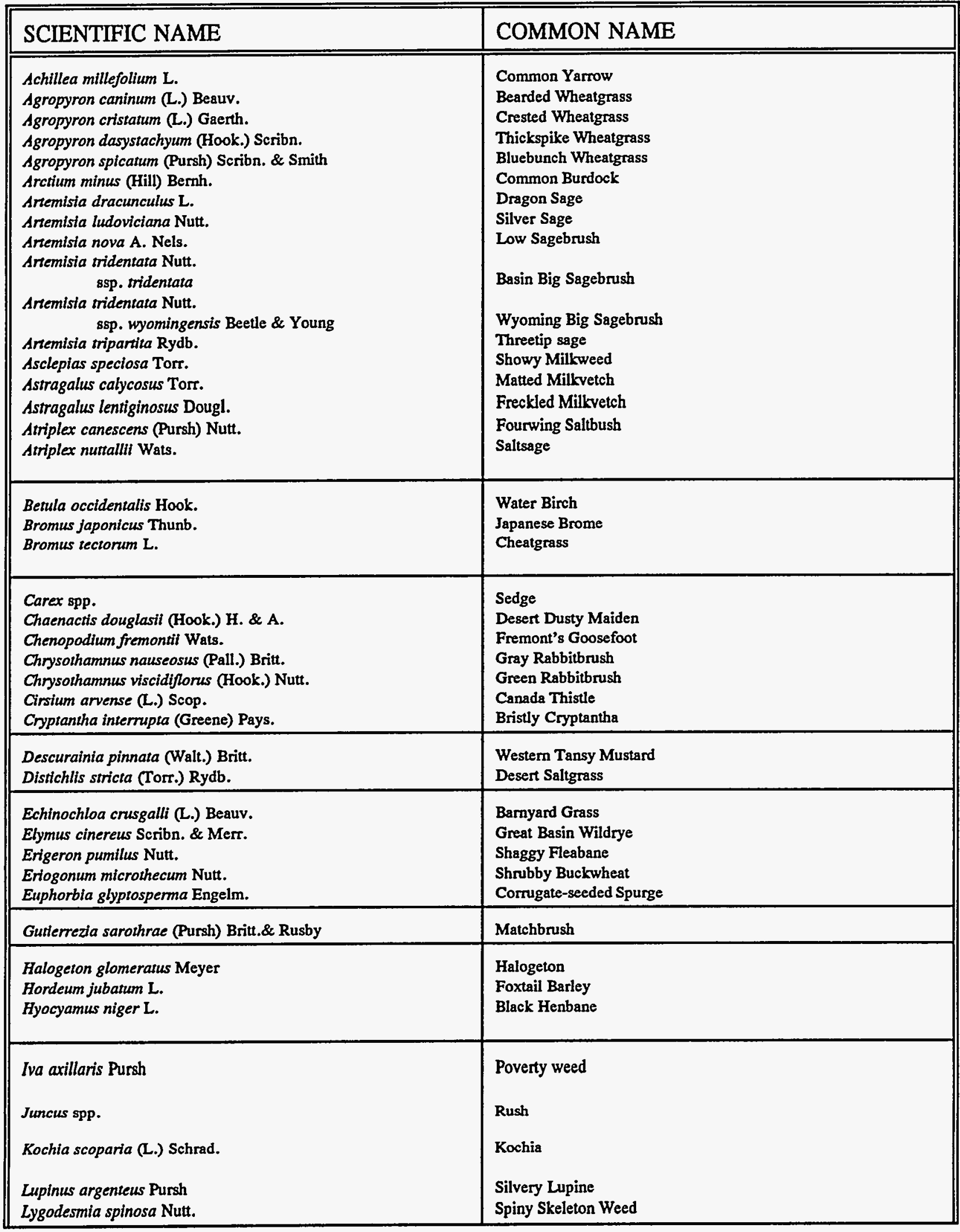




\begin{tabular}{|c|c|}
\hline SCIENTIFIC NAME & COMMON NAME \\
\hline $\begin{array}{l}\text { Machaeranthera canescens (Pursh) Gray } \\
\text { Medicago lupulina L. } \\
\text { Medicago sativa L. } \\
\text { Melilotus officinalis (L.) Lam. }\end{array}$ & $\begin{array}{l}\text { Hoary Aster } \\
\text { Black Medic } \\
\text { Alfalfa } \\
\text { Yellow Sweet-clover }\end{array}$ \\
\hline $\begin{array}{l}\text { Oenothera caespitosa Nutt. } \\
\text { Oenothera zanacetifolia T. \& G. } \\
\text { Opuntia polyacantha Haw. } \\
\text { Orobanche fasciculata Nutt. } \\
\text { Oryzopsis hymenoides (R. \& S.) Ricker }\end{array}$ & $\begin{array}{l}\text { Desert Evening Primrose } \\
\text { Tansy-lvd Evening Primrose } \\
\text { Prickly Pear } \\
\text { Clustered Broomrape } \\
\text { Indian Ricegrass }\end{array}$ \\
\hline $\begin{array}{l}\text { Phlax hoodii Rich. } \\
\text { Poa nevadensis Vasey } \\
\text { Poa sandbergii Vasey } \\
\text { Polygonum aviculare L. } \\
\text { Polygonum douglasii Greene } \\
\text { Populus angustifolia James } \\
\text { Populus trichocarpa T. \& G. } \\
\text { Prumus virginiana L. }\end{array}$ & $\begin{array}{l}\text { Hood's Phlox } \\
\text { Nevada Bluegrass } \\
\text { Sandberg's Bluegrass } \\
\text { Doorweed } \\
\text { Douglas' Knotweed } \\
\text { Narrow-leaved Cottonwood } \\
\text { Black Cottonwood } \\
\text { Common Chokecherry }\end{array}$ \\
\hline $\begin{array}{l}\text { Ribes aureum Pursh } \\
\text { Rosa woodsii Lindl. } \\
\text { Rumex crispus L. }\end{array}$ & $\begin{array}{l}\text { Golden Currant } \\
\text { Wood's Rose } \\
\text { Curly Dock }\end{array}$ \\
\hline $\begin{array}{l}\text { Salix exigua Nutt. } \\
\text { Salsola kali L. } \\
\text { Scirpus acutus Muhl. } \\
\text { Scirpus spp. } \\
\text { Sisymbrium altissimum L. } \\
\text { Sitanion hystrix (Nutt.) Smith } \\
\text { Solanum triflorum Nutt. } \\
\text { Solidago canadensis L. } \\
\text { Sphaeralcea mumroana (Dougl.) Spach. } \\
\text { Stipa comata Trin. \& Rupr. }\end{array}$ & $\begin{array}{l}\text { Gray Sandbar Willow } \\
\text { Russian Thistle } \\
\text { Hardstem Bulrush } \\
\text { Bulrush } \\
\text { Jim Hill Mustard } \\
\text { Bottlebrush Squirreltail } \\
\text { Cut-leaved Nightshade } \\
\text { Canada Goldenrod } \\
\text { Orange Globemallow } \\
\text { Needle-and-thread Grass }\end{array}$ \\
\hline $\begin{array}{l}\text { Typha latifolia } \mathrm{L} \text {. } \\
\text { Urtica dioica } \mathrm{L} \text {. }\end{array}$ & $\begin{array}{l}\text { Common Cattail } \\
\text { Stinging Nettle }\end{array}$ \\
\hline
\end{tabular}




\section{APPENDIX D}

D-1 


\section{Preliminary Survey Of The National Wetlands Inventory As Mapped For The Idaho National Engineering Laboratory}

(Reference: INEL-95/0101)

\section{LEGEND}

\section{L2USJ : $\mathrm{L}=$ Lacustrine, 2 = Littoral}

US = Unconsolidated Shore,

PAB4Hx : $\mathbf{P}=$ Palustrine, $\mathrm{AB}$ - Aquatic Bed

4 = Floating Vascular, $\mathrm{H}=$ Permanently Flooded,

$X=$ Excavated

$\square$ PEMJ $: \mathbf{P}=$ Palustrine, $\mathrm{EM}=$ Emergent

$\mathbf{J}=$ Intermittently Flooded

PEM1A : $\mathbf{P}=$ Palustrine, $\mathrm{EM}=$ Emergent, $1=$ Persistent,

A $=$ Temporarily Flooded

$\square$ PEMIC : $\mathbf{P}=$ Palustrine, $\mathrm{EM}=$ Emergent, 1 = Persistent, $\mathrm{C}=$ Seasonally Flooded

$\square$ PEMIJ : $P$ = Palustrine, $E M=$ Emergent, 1 = Persistent, $\mathbf{J}=$ Intermittently Flooded

POWHx : $\mathbf{P}=$ Palustrine, OW = Open Water

$\mathbf{H}_{\mathbf{H}} \mathbf{P}=$ Permanently Flooded, $\mathrm{x}=$ Excavated

PUSC : $\mathbf{P}=$ Palustrine, US = Unconsolidated Shore, $\mathbf{C}=$ Seasonally Flooded

PUSCrx : P = Palustrine, US = Unconsolidated Shore,

$\mathrm{C}=$ Seasonally Flooded, $\mathbf{r}=$ Artificial Substrate,

$\mathrm{X}=$ Excavated

PUSCx : $\mathbf{p}=$ Palustrine, US = Unconsolidated Shore,

$\mathrm{C}=$ Seasonally Flooded, $\mathrm{x}=$ Excavated

PUSJ : $\mathrm{P}=$ Palustrine, US = Unconsolidated Shore, $\mathrm{J}=$ Intermittently Flooded

UPLAND : Non Wetland

- R2OWHx : $\mathrm{R}=$ Riverine, $2=$ Lower Perennial, OW $=$ Open Water, $\mathrm{H}=$ Permanently Flooded,

- $\quad x=$ Excavated

- R4SBA : $\mathrm{R}=$ Riverine, 4 = Intermittent, $\mathrm{SB}=$ Streambed

$\begin{aligned} \mathrm{R} 4 \mathrm{SBC}: \mathrm{R} & =\text { Riverine, } 4=\text { Interm } \\ \mathrm{C} & =\text { Seasonally Flooded }\end{aligned}$

- $\mathrm{R} 4 \mathrm{SBJ}: \mathrm{R}=$ Riverine, $4=$ Intermittent, $\mathrm{SB}=$ Streambed, $\mathbf{J}=$ Intermittently Flooded

- R4SBJx : $\mathbf{R}=$ Riverine, $4=$ Intermittent, $\mathrm{SB}=$ Streambed $\mathbf{J}=$ Intermittently Flooded, $\mathrm{x}=$ Excavated

- R4SBKCx: $\mathbf{R}=$ Riverine, $4=$ Intermittent, $\mathrm{SB}=$ Streambed $\mathrm{K}=$ Artificially Flooded, $\mathbf{C}=$ Seasonally Flooded, $\mathrm{x}=$ Excavated

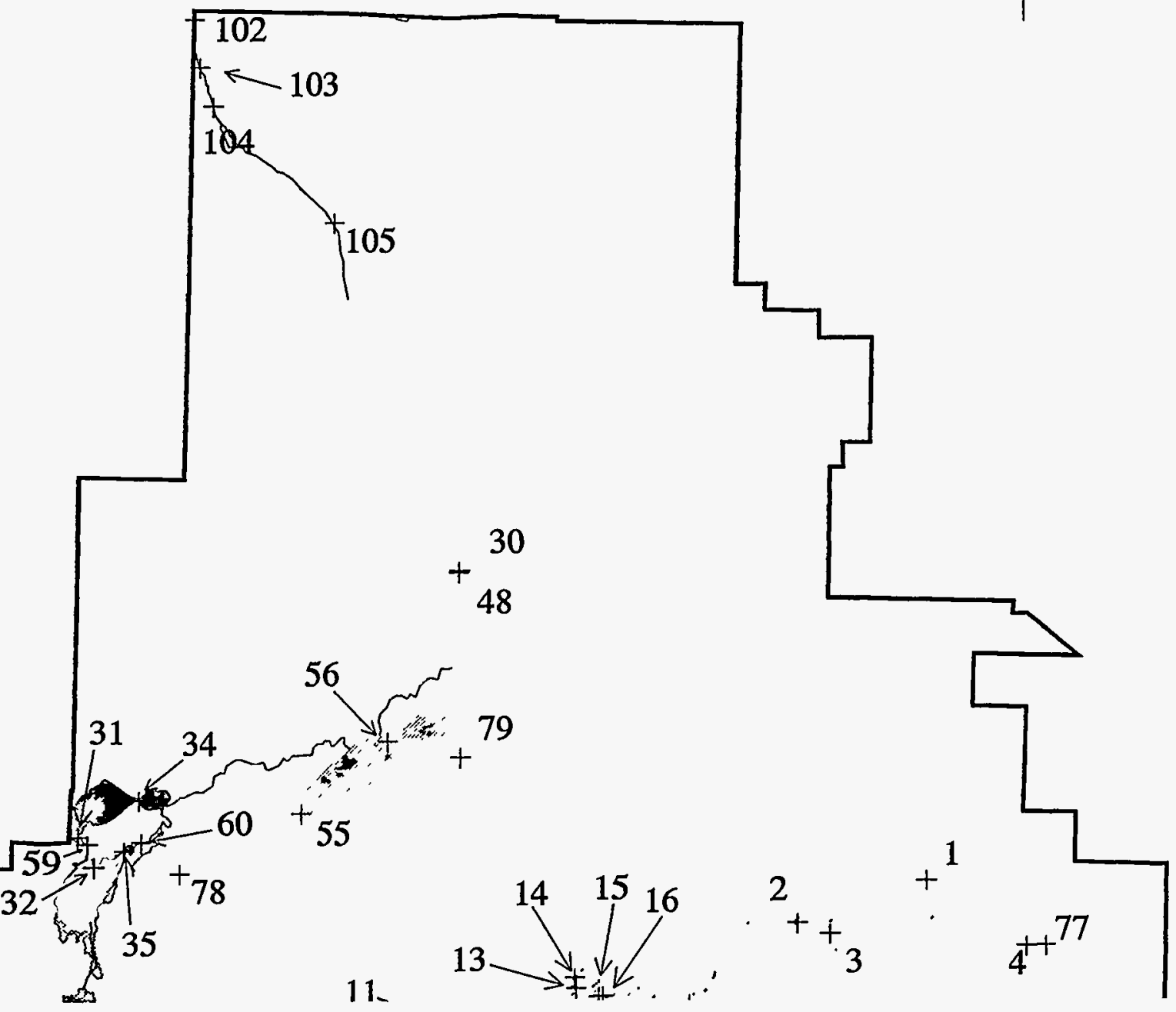


